\title{
Hydrothermal activity and magma genesis along a propagating back-arc basin: Valu Fa Ridge (southern Lau Basin)
}

\author{
S. Fretzdorff, ${ }^{1}$ U. Schwarz-Schampera, ${ }^{2}$ H. L. Gibson, ${ }^{3}$ C.-D. Garbe-Schönberg, ${ }^{1}$ \\ F. Hauff, ${ }^{4}$ and P. Stoffers ${ }^{1}$ \\ Received 28 July 2005; revised 14 December 2005; accepted 1 March 2006; published 26 August 2006.
}

[1] Valu Fa Ridge is an intraoceanic back-arc spreading center located at the southern prolongation of the Lau basin. Bathymetric observations as well as detailed sampling have been carried out along the spreading axis in order to trace hydrothermal and volcanic activity and to study magma generation processes. The survey shows that widespread lava flows from recent volcanic eruptions covered most of the Vai Lili hydrothermal vent field; only diffuse low-temperature discharge and the formation of thin layers of siliceous precipitates have been observed. Evidence of present-day hydrothermal activity at the Hine Hina site is indicated by a thermal anomaly in the overlying water column. Our studies did not reveal any signs of hydrothermal activity either above the seismically imaged magma chamber at $22^{\circ} 25^{\prime} \mathrm{S}$ or across the southern rift fault zone $\left(22^{\circ} 51^{\prime} \mathrm{S}\right)$. Lavas recovered along the Valu Fa Ridge range from basaltic andesites to rhyolites with $\mathrm{SiO}_{2}$ contents higher than reported from any other intraoceanic back-arc basin. On the basis of the highly variable degrees of crystal fractionation along axis, the development of small disconnected magma bodies is suggested. In addition, the geochemical character of the volcanic rocks shows that the transition zone from oceanic spreading to propagating rifting is located south of the Hine Hina vent field in the vicinity of $22^{\circ} 35^{\prime} \mathrm{S}$.

Citation: Fretzdorff, S., U. Schwarz-Schampera, H. L. Gibson, C.-D. Garbe-Schönberg, F. Hauff, and P. Stoffers (2006), Hydrothermal activity and magma genesis along a propagating back-arc basin: Valu Fa Ridge (southern Lau Basin), J. Geophys. Res., 111, B08205, doi:10.1029/2005JB003967.

\section{Introduction}

[2] Propagating spreading centers are bounded by pseudofaults with a V-shaped appearance pointing toward the direction of migration of the spreading axis [e.g., Hey, 1977; Hey et al., 1989]. It has been recently suggested that magma generation beneath propagating spreading centers works independent of its location at mid-ocean ridges or backarc basins [Fleutelot et al., 2005]. This paper presents new bathymetric and geochemical data from the Valu Fa Ridge; a propagating back-arc spreading center located at the southern prolongation of the Lau basin. The studied region is characterized by intense tectonic and magmatic activity and represents an excellent example to study magma generation processes [e.g., Peate et al., 2001; Martinez and Taylor, 2002, 2003; Taylor and Martinez, 2003]. Highly differentiated lavas have been erupted at Valu Fa Ridge [e.g., Vallier et al., 1991], with $\mathrm{SiO}_{2}$ contents higher

\footnotetext{
${ }^{1}$ Institut für Geowissenschaften, Abteilung Geochemie, ChristianAlbrechts-Universität zu Kiel, Kiel, Germany.

${ }^{2}$ Bundesanstalt für Geowissenschaften und Rohstoffe (BGR), Hannover, Germany.

${ }^{3}$ Department of Earth Sciences, Laurentian University, Sudbury, Ontario, Canada.

${ }^{4}$ IFM-Geomar, Dienstgebäude Ostufer, Kiel, Germany.

Copyright 2006 by the American Geophysical Union. 0148-0227/06/2005JB003967\$09.00
}

than reported from any other oceanic back-arc basin or midocean ridge. Several authors [e.g., Fouquet et al., 1993; Perfit et al., 1999] have suggested that the development of hydrothermal systems is often associated with the emplacement of silica-rich volcanic rocks, and have proposed a genetic relationship between magmatism, tectonism and hydrothermal activity along oceanic spreading ridges. In November 2002, the R/V Sonne (cruise SO167) surveyed the area between $22^{\circ} \mathrm{S}$ and $23^{\circ} \mathrm{S}$ with high-resolution swath bathymetry (Figure 1b), back-scattered imaging and video observation to locate recent tectonic, magmatic, and hydrothermal activity and to investigate the onset of coeval magma-induced hydrothermal activity. Furthermore, the rift and seamount structures south of the Valu Fa Ridge were studied in detail to identify tectonic propagators and to explore a possible relation between hydrothermalism and evolving propagating rift tips (auxiliary material). ${ }^{1}$

[3] Fresh volcanic rocks were sampled at the spreading segments, the southern propagating rift tip and at bathymetric highs south of the Valu Fa spreading axis (Figure 1b). The bathymetry and structural interpretations for the southern Valu Fa Ridge are presented here along with geochemical data of the lavas. These data are used to evaluate the extent of subduction processes influencing magma genera-

\footnotetext{
${ }^{1}$ Auxiliary materials are available at $\mathrm{ftp} / / \mathrm{ftp}$.agu.org/apend/jb/ $2005 \mathrm{jb} 003967$.
} 


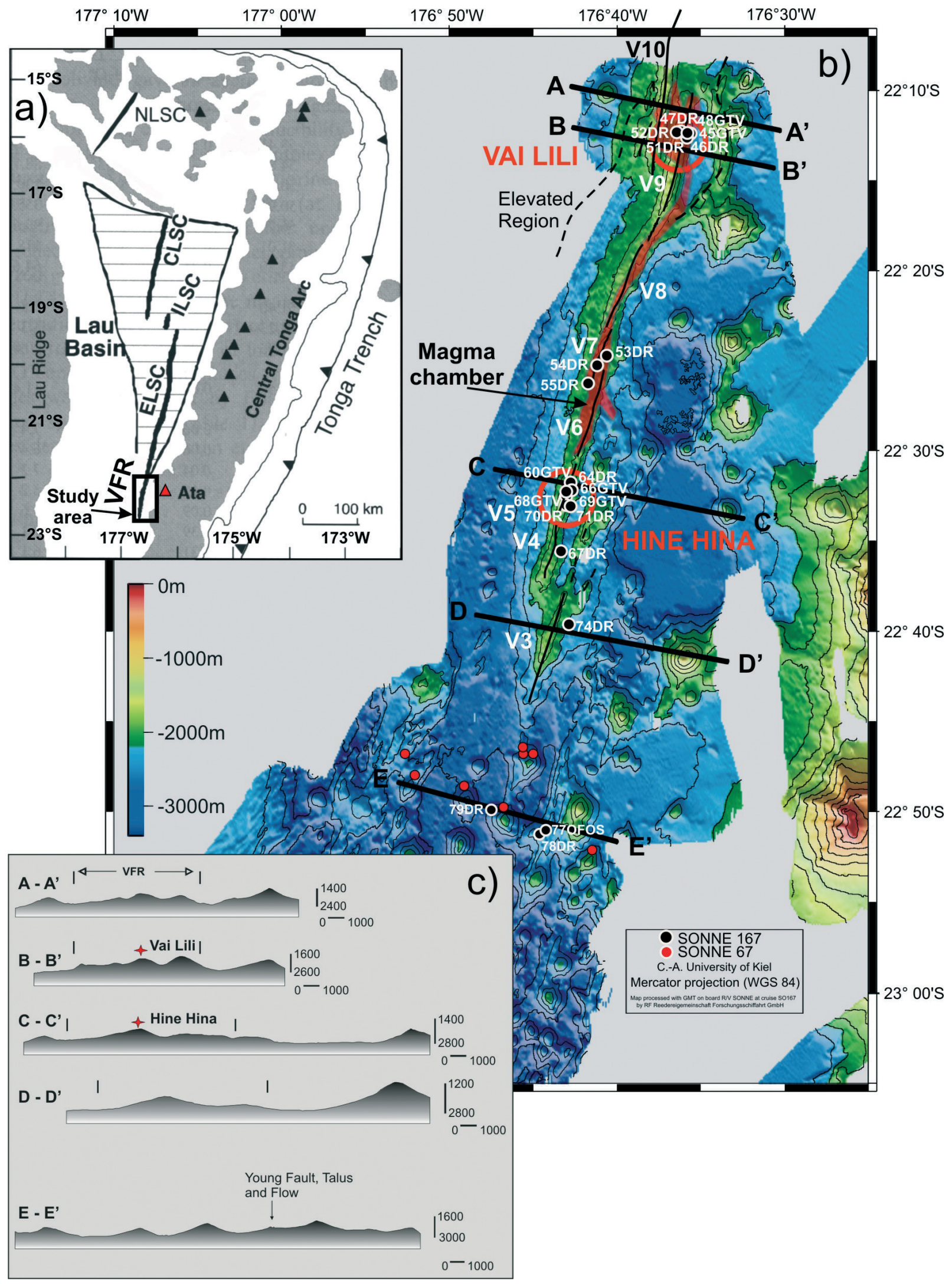

Figure 1 
tion beneath the propagating Valu Fa Ridge and to explore rift tectonic processes and related volcanism.

\section{Tectonic Setting}

[4] The triangular shaped Lau Basin is composed of three major, active spreading ridges, the Central Lau Spreading Center (CLSC), the Eastern Lau Spreading Center (ELSC), and the southernmost part south of $21^{\circ} 20 \mathrm{~s}$, which is referred to as the Valu Fa Ridge [Jenner et al., 1987; Vallier et al., 1991] (Figure 1a). Over the past 5-5.5 Myr, the Lau Basin back arc opened by successive southward propagation of seafloor spreading centers [Hawkins, 1995a, 1995b]. It is one of the fastest spreading back-arc centers in the world with full rates between $90 \mathrm{~mm} / \mathrm{yr}$ at $18^{\circ} \mathrm{S}$ and $65 \mathrm{~mm} / \mathrm{yr}$ at $21^{\circ} \mathrm{S}$ [Taylor et al., 1996]. Subduction rates of the 100 to $140 \mathrm{Ma}$ Pacific plate along the Tonga trench vary between $240 \mathrm{~mm} / \mathrm{yr}$ in the north and $165 \mathrm{~mm} / \mathrm{yr}$ in the south [Bevis et al., 1995]. The Valu Fa spreading ridge extends for at least $165 \mathrm{~km}$, is 5 to 6 kilometers wide with ridge flanks rising about $600 \mathrm{~m}$ above the surrounding seafloor and is propagating southward into Miocene island arc crust at about $22^{\circ} 45^{\prime} \mathrm{S}$ [Wiedicke and Collier, 1993; Taylor et al., 1996]. The close proximity to the Tofua arc, about $40 \mathrm{~km}$ to the west, makes this back-arc region in particular interesting for studying interactions between the mantle wedge and the subducting slab. Geophysical studies [e.g., Stackelberg and the Shipboard Scientific Party, 1988] suggest that the Valu Fa Ridge is divided into three ridge sections, i.e., the southern, central and northern Valu Fa Ridge (SVFR, CVFR, NVFR). However, Wiedicke and Collier [1993] interpreted a much more differentiated ridge segmentation and recognized 11 volcanic ridge edifices named V3 to V14 (V3 to V6 belong to the SVFR, V7 to V9 to the CVFR, and V10 to V14 to the NVFR; Figure 1b). Apart from the three main overlapping spreading segments, the offsets between the individual segments are generally in the order of $0.4-$ $2.3 \mathrm{~km}$ and affect only the neovolcanic zone at the ridge crest [Wiedicke and Collier, 1993]. From the detailed bathymetric map recorded during SO167 it is clear that besides the active ridge axis, several seamounts of unknown origin occur south of the ridge tip and possibly mark juvenile magmatic activity as a precursor to the evolving rift.

[5] Seismic data indicate that the central Valu Fa Ridge is underlain by a steady axial magma chamber [Collier and Sinha, 1990, 1992; Day et al., 2001] (Figure 1a). The reflection is continuous for at least $10 \mathrm{~km}$, and may extend to $20 \mathrm{~km}$ on a profile recorded along the entire axis of the Valu Fa Ridge from $22^{\circ} 10$ to $22^{\circ} 30$ (Figure 1b) [e.g., Collier and Sinha, 1992]. The top of the magma reservoir is interpreted to be $2-3 \mathrm{~km}$ wide and located $3.2 \mathrm{~km}$ below the seafloor which is relatively deep compared to those found along mid-ocean ridges (e.g., $1.2-2.4 \mathrm{~km}$ beneath the East Pacific Rise [Detrick et al., 1987]). The well-defined seismic reflectors, and a large reflective coefficient, as well as the flattened top are most likely related to a low-density, highly viscous siliceous melt. A discontinuity in the seismic record toward the CVFR probably reflects thinning of the crystal mush zone and would imply that the overlapping spreading center between CVFR and NVFR (between V10 and V9 on Figure 1b) is currently the site of enhanced magmatism [Turner et al., 1999; Day et al., 2001]. Hydrothermal plume mapping over the Valu Fa Ridge found that the plume coverage is comparable to the global trend for MORs spreading at similar rates [Baker et al., 2005].

\section{Bathymetric Observation: Morphology, Hydrothermal, and Volcanic Activity}

[6] Bathymetric profiles and video observations across the Valu Fa Ridge spreading axis have been recorded in order to trace hydrothermal and volcanic activity. From north to south there is a systematic eastward shift in the propagation of the ridge axis and en echelon orientation of the ridge segments (Figure 1). The topography of the Valu Fa Ridge is rather flat, comparable to fast spreading midocean ridges (Figure 1c). To the south, the Valu Fa Ridge evolves into a system of tectonic half graben and graben.

[7] The Vai Lili and Hine Hina hydrothermal fields are located at overlapping ridge segments on topographical highs (Figure 1c). Below follows a brief overview of the segments from north (V9) to south (V5) with representative seafloor photos showing hydrothermal precipitates and volcanic deposits (Figure 2).

\subsection{Vai Lili Segment}

[8] In 1989, the French submersible Nautile discovered the Vai Lili hydrothermal field and found high-temperature black and white smokers [Fouquet et al., 1989, 1991, 1993]. Apart from the hydrothermal deposits, they identified brecciated lava forming eruptional cones and black rippled volcaniclastic debris in the Vai Lili area. Fouquet et al. [1993] have suggested that Vai Lili is in a volcanic/tectonic stage. During SO167, our survey showed significant interim changes of the Vai Lili hydrothermal vent field. We observe the coverage of the Vai Lili area by sediment-free, glassy "aa-type" aphyric lava that were mapped over an area of $850 \mathrm{~m} \times 400 \mathrm{~m}$ (Figure 2a). Since the flows were not noticed during previous surveys [cf. Fouquet et al., 1989, 1993] a revival of volcanism is suggested. This is in accordance with geophysical observations which locate

Figure 1. (a) Tectonic map of the Tonga-Lau arc-back-arc system redrawn after Peate et al. [2001]. VFR, Valu Fa Ridge; ELSC, Eastern Lau Spreading Center; ILSC, Intermediate Lau Spreading Center; CLSC, Central Lau Spreading Center; NLSC, Northern Lau Spreading Center. (b) Seafloor bathymetry of the central and southern Valu Fa Ridge, as recorded and processed by the multichannel SIMRAD EM 120 system during SO167. Sample locations of SO167 are indicated with a black circle, and additional stations from an earlier cruise SO67 in 1990 are marked with a red circle. Seismic data indicate a steady axial magma chamber (highlighted in red [after Day et al., 2001]). (c) Morphology of the central and southern Valu Fa Ridge. The five profiles show a rather flat and smooth topography comparable with fast spreading mid-ocean ridges. Despite the extrusion of higher differentiated, silica-rich volcanic flows, the ridge does not represent a significant morphological axial high. To the south, the Valu Fa Ridge develops into a system of half grabens. 

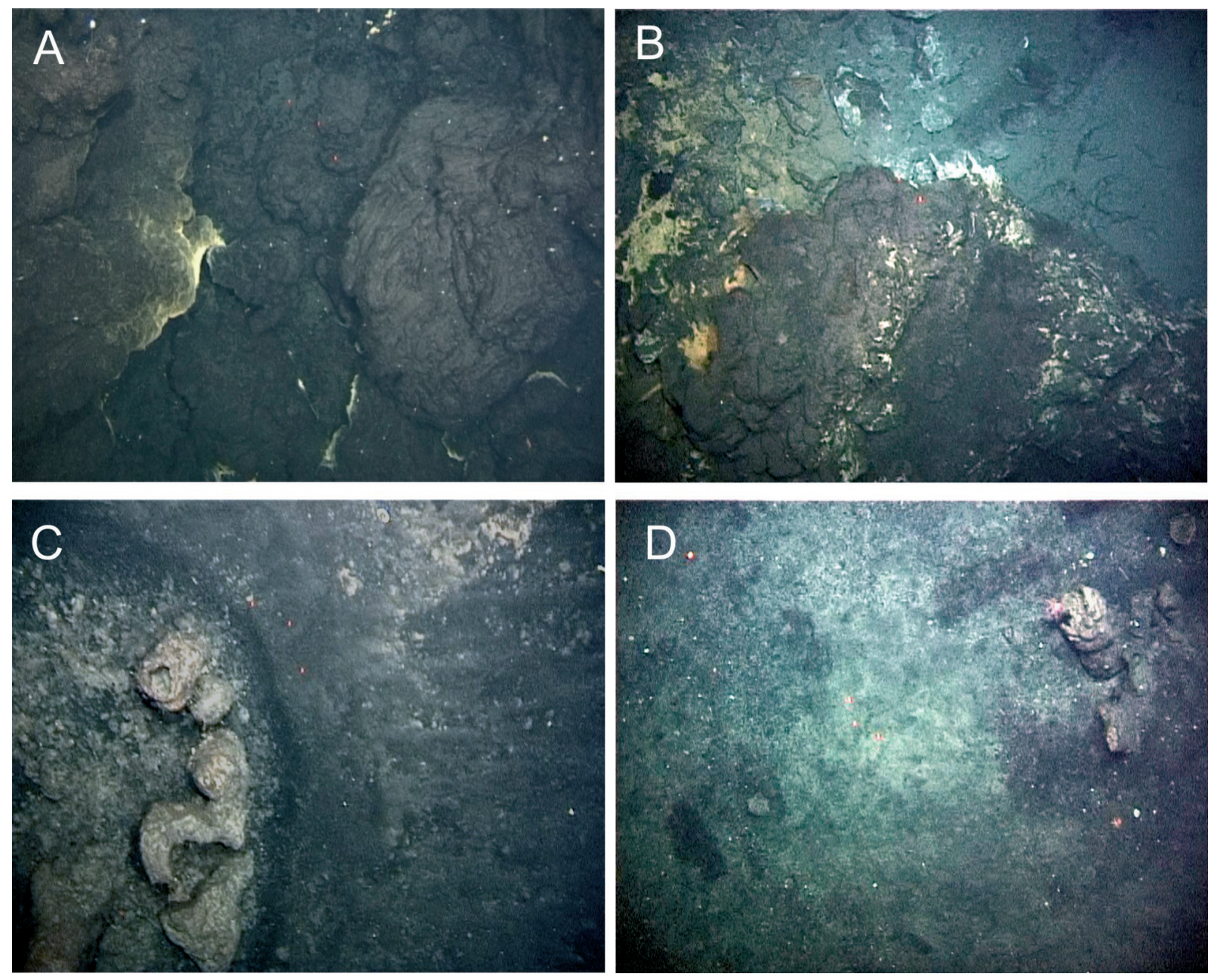

Figure 2. Seafloor photographs showing hydrothermal activity, precipitates and volcanism along the central and southern Valu Fa Ridge. (a) Glassy aa-type aphyric lava with white hydrothermal silica precipitates at Vai Lili site. (b) Fresh aa-type flow covering hydrothermally altered host rocks of the Vai Lili site. (c) Hydrothermal mound with extinct sulfide chimneys surrounded by volcanic sand (Hine Hina hydrothermal field). (d) Extinct chimneys partly buried by black volcaniclastic sand (Hine Hina site).

the greatest crustal thickness beneath this overlapping spreading center and has been interpreted to focus upwelling melt and thereby enhance magmatism [Turner et al., 1999; Day et al., 2001].

[9] Sampling of the recent lava flows by dredging and TVguided grab revealed neither hydrothermal alteration nor a massive sulfide-forming system (Figures $2 a$ and $2 b$ ). Beside the aa-type flows, pillow lavas are observed $(250 \mathrm{~m} \times$ $150 \mathrm{~m}$ ) along a north-south bounded elongated horst-like structure. Assuming the pillow lava flow is younger than the aa-type lavas, the occurrence of white, hydrothermally altered basalt xenoliths in unaltered aa lava indicates that the aa-type flow was erupted after or during an earlier mineralization event. The active chimneys identified during the NAUTILAU cruise [Fouquet et al., 1989, 1991, 1993] were not observed during our survey. Instead, dead colonies of hydrothermal vent fauna, single oxidized chimneys and altered and mineralized volcanic clasts (Figure 2b) in the interstices of lobate flows were found. As both our OFOS and TV-guided grab positioning was well constrained during the tracks, we suggest that recent volcanic eruptions covered most of the hydrothermal Vai Lili vent field. Ongoing hydrothermal activity at the former Vai Lili site was recorded by diffuse low-temperature discharge with thermal anomalies between $0.14^{\circ} \mathrm{C}$ and $0.25^{\circ} \mathrm{C}$ about $3 \mathrm{~m}$ above seafloor and the formation of thin layers of siliceous and sulfurous precipitates on glassy lavas and along the rims of the lobes (Figures 2a and 2b). Recently, the distribution of hydrothermal plumes in the water column along the Valu Fa Ridge has been studied [Baker et al., 2005]. About $3 \mathrm{~km}$ north of Vai Lili site, Baker et al. [2005] mapped the most intense and extensive plume signal of the surveyed area and suggest that the plume source is located at the southern end of the NVFR.

\subsection{Central Valu Fa Ridge}

[10] The small distance $(2-3 \mathrm{~km})$ between two lines of volcanic edifices and the lack of off-ridge structures were interpreted in terms of rapid and fairly recent southward extension of this segment [Wiedicke and Collier, 1993]. A strong temperature anomaly was reported close to the southern end of the CVFR ridge axis at $22^{\circ} 25.90$ s within 
$200 \mathrm{~m}$ above seafloor based on XBT profiles [Peirce et al., 1996]. Our SIMRAD mapping showed small-scale ridge axis discontinuities up to $250 \mathrm{~m}$ marked by volcanic edifices that are about $120-200 \mathrm{~m}$ high in water depths between $2000 \mathrm{~m}$ and $1940 \mathrm{~m}$. The whole ridge segment has an asymmetric shape, with steeper slopes on the eastern side to water depths of about $2200 \mathrm{~m}$ and shallow slopes toward the west $(2100 \mathrm{~m})$. Video observations verified that this ridge segment is in a tectonic stage that lacks any evidence of recent volcanic activity. The top of the ridge is dominated by lobate and minor pillow lava flows that are partially covered by gray pelagic sediment. The occurrence of numerous fissures and no evidence of recent (i.e., nonsedimented) volcanic rocks or volcaniclastic sediments suggests that this ridge segment has been volcanically inactive for some time. Still this segment appears tectonically active as a result of continued extension and associated spreading. Our survey did not reveal any signs of ongoing hydrothermal activity (i.e., hydrothermal crust or vent fauna associated with hydrothermal activity) or thermal anomalies in the overlying water column due to diffuse low-temperature discharge. The reported temperature anomaly in the southern part of the segment could not be verified. Single outcrops displayed reddish to yellowish staining which is probably related to cold seawater alteration. Sampling was carried out during three dredges on bathymetric highs of single volcanic edifices in water depths between $2120 \mathrm{~m}$ and $1900 \mathrm{~m}$, above the magma chamber (Figure 1b).

\subsection{Hine Hina Segment}

[11] Prior to SO 167 the Hine Hina hydrothermal field was surveyed in 1989 [Fouquet et al., 1989, 1991, 1993]. Important observations were that Hine Hina is in a volcanic stage and that the hydrothermal system is divided into two topographically distinct parts [e.g., Fouquet et al., 1993]. The deeper part is hosted by massive lava flows and has a focused discharge along faults while the upper parts are characterized by volcaniclastic material and diffuse lowtemperature venting. In contrast to the significant changes observed at the Vai Lili site, the morphology, tectonic fabric, the volcanological and hydrothermal features at this ridge segment have not changed significantly since the last survey in 1989. We suggest that extensive low-temperature diffuse hydrothermal discharge at the Hine Hina site is a product of a volcanic environment which is markedly different from that of the Vai Lili segment. Extensive deposits of black volcaniclastic sand occur for more than $1000 \mathrm{~m}$ along the top and the entire western flank of the ridge segment, larger than documented in 1989. Mapping and TV-guided sampling indicate that the black-gray volcanic sand underlies a hydrothermal Fe-Mn oxyhydroxide crust where it may attain thicknesses of several meters. Locally, up to $35 \mathrm{~cm}$ sized volcanic bombs with thick glass crusts were observed. The morphology of the sand grains, the occurrence of bombs and the volume of sand are consistent with an origin from several small explosive magmatic and hydrovolcanic eruptions. The thin $(<5-7 \mathrm{~cm}$ thick) but extensive Fe-Mn oxyhydroxide crust covers much of the upper part of the ridge. It may be a product of unfocused, diffuse lowtemperature hydrothermal discharge, facilitated by the permeability of the underlying porous volcanic sand. Hydrothermal activity probably continued after eruptions, as suggested by altered and mineralized clasts resting on the volcanic sand, sulphide talus and inactive chimneys on lobate flows and partly buried by sand (Figure 2c) and the development of thick Fe-Mn oxyhydroxide crusts on the surface of some lava fragments (Figure 2d). Evidence of present-day hydrothermal activity is indicated by whiteyellow bacterial mats and shimmering water along a fault scarp in massive lava. Temperature anomalies between $0.05^{\circ} \mathrm{C}$ and $0.22^{\circ} \mathrm{C}$ (about $3 \mathrm{~m}$ above seafloor) indicate that these faults are preferential pathways for discharging lowtemperature fluids. Baker et al. [2005] found no anomalies over the Hine Hina site, but identified two to three previously unknown locations farther south between $22^{\circ} 27^{\prime} \mathrm{S}$ $22^{\circ} 31^{\prime} \mathrm{S}$ with up to $\sim 0.008^{\circ} \mathrm{C}$ anomalies within $20 \mathrm{~m}$ above seafloor [Baker et al., 2005].

\subsection{Southern Rift Fault Zone $\left(22^{\circ} 51^{\prime} S\right)$}

[12] The Valu Fa spreading ridge ends at $22^{\circ} 45^{\prime} \mathrm{S}$, while two large seamounts immediately south of the ridge tip may represent the initial stage of southward ridge propagation [Wiedicke and Collier, 1993]. Structures south of the ridge tip indicate distinct faults that parallel the regional strike of the VFR $\left(\mathrm{N} 20^{\circ} \mathrm{E}\right)$ and its eastward offset (Figure 1c). Bathymetric highs of inferred sedimented island arc crust SE of the southernmost Valu Fa Ridge segment are bounded by one of the largest fault zones [Wiedicke and Collier, 1993]. During SO167, we surveyed a crust segment along the SE extension of the southern Valu Fa Ridge tip at $22^{\circ} 51.40 \mathrm{~s}, 176^{\circ} 44.40^{\prime} \mathrm{W}$. The large-scale westward facing fault zone indicates the eastern limit of a neovolcanic zone and may represent one of the major structures for recent volcanic eruptions (Figure 1c). The objectives of our work in this area were to define and map structures that may represent the southern rift propagator, and to locate any sites of recent rift-related volcanism and/or hydrothermal activity. An east-west orientated, $1 \mathrm{~km}$ long, video observation traverse showed that most of the ocean floor in this area is represented by older ocean floor and volcanic edifices covered by a relatively thick (centimeters to decimeters) light gray sediment blanket. Ridges of lobate flows and talus are interpreted to trace faults within the relatively smooth, flat sediment-covered ocean floor. A prominent, $100 \mathrm{~m}$ wide and almost $50 \mathrm{~m}$ deep rift graben subparallel to the strike of the Valu Fa Ridge may represent the volcanically and tectonically active southern propagator. The graben is characterized by vertical walls with blocky talus and young lobate and tubular flows covering the graben floor. The location of the graben on a topographic high may be related to magmatic doming as well as high-level magma emplacement and would suggest that this fault is part of the actively southward propagating Valu Fa rift system close to the Tonga arc $40 \mathrm{~km}$ east of the ridge.

\section{Sampling}

[13] The central Valu Fa Ridge at segment V9 $\left(22^{\circ} 13^{\prime} \mathrm{S}\right)$ hosting the Vai Lili hydrothermal vent field, the southward propagating segment V7 $\left(22^{\circ} 25^{\prime} \mathrm{S}\right)$, the segments V5 $\left(22^{\circ} 32^{\prime} \mathrm{S}\right)$ hosting the Hine Hina hydrothermal field and V3 $\left(22^{\circ} 40 \mathrm{~s}\right)$ at the ridge tip, and the propagating rift in the southward extension of the spreading axis $\left(22^{\circ} 51^{\prime} \mathrm{S}\right)$ have been mapped and sampled with dredges and a TV-guided 
grab (Figure 1b). In addition, a series of rock samples from seamounts south of the Valu Fa Ridge, recovered during R/V Sonne cruise SO67 in 1990 (Figure 1a) [Stackelberg, 1990], were included in order to more fully constrain magma generation south of the propagating rift.

[14] Samples from the Vai Lili site are mostly fresh aphyric lava covered with glassy rims, similar to segment V7 and V5 (Hine Hina vent field) where fresh glassy aphyric pillow fragments were obtained. At Hine Hina black volcanic sand, Fe-Mn crusts, altered and sulphide mineralized rock fragments have been also recovered. The southernmost segment provided fresh glassy plagioclasephyric lava, aphyric pillow fragments, but also black aphyric volcanic sand and Fe-Mn crusts that are comparable to those found at Hine Hina. A variety of rock types including fresh glassy aphyric lava fragments, olivine basalt and plagioclase phyric lava locally covered with Fe-oxyhydroxide patches were recovered from the southern rift fault zone.

\section{Geochemistry}

\subsection{Major and Trace Elements}

[15] Major and trace element analyses are presented in Table 1. The Valu Fa Ridge samples range from basaltic andesite to rhyolite and are members of the low-K series, with a few seamount lavas south of the ridge tip showing medium-K basaltic composition (Figure 3). Interestingly, volcanics from segment $\mathrm{V} 7$ have $\mathrm{SiO}_{2}$ contents up to $72 \mathrm{wt} \%$, higher than reported from any other intraoceanic back-arc basin, and are likely to reflect extensive crystal fractionation. Although the seismically imaged magma chamber underlies the ridge from $22^{\circ} 10^{\prime} \mathrm{S}$ to $22^{\circ} 30^{\prime} \mathrm{S}$ [e.g., Collier and Sinha, 1992] (Figure 1b), dacites and rhyolites have only been erupted at the southern end of the magma chamber. Lavas from the southern tip and seamounts south of the spreading ridge are enriched in $\mathrm{K}_{2} \mathrm{O}$ (wt \%) and lie within the geochemical field of the central Tonga arc (Figure 3). Generally, the Tonga arc is characterized by higher $\mathrm{K}_{2} \mathrm{O}$ at similar $\mathrm{SiO}_{2}$ concentrations, compared to the Valu Fa Ridge and Lau Basin lavas, while latter have distinct lower $\mathrm{K}_{2} \mathrm{O}$ values (Figure 3).

[16] According to experimental data, incompatible elements such as $\mathrm{Na}_{2} \mathrm{O}$ are diluted in the melt as the degree of melting increases [e.g., Falloon et al., 1988; Hirose and Kushiro, 1993; Hirose and Kawamoto, 1995]. In order to evaluate the melting processes beneath the Valu Fa Ridge, the geochemistry is corrected for the effects of crystal fractionation by calculating the $\mathrm{Na}_{2} \mathrm{O}$ contents to a common $8 \% \mathrm{MgO}$ after Plank and Langmuir [1992]. In order to limit possible errors, only samples with $>2 \% \mathrm{MgO}$ were selected. There is a slight decrease in $\mathrm{Na}_{8}$ values of the samples from north to south (Figure 4). The Vai Lili region shows highest $\mathrm{Na}_{8}$ composition and is also characterized by a broad range of $\mathrm{Na}_{8}$ values. Lowest $\mathrm{Na}_{8}$ lavas occur at a seamount located in the prolongation of the V3 segment (see location in Figure 1 and see Figure 4). Generally, $\mathrm{Na}_{8}$ values at the southern tip of the ridge are lower than those calculated for Ata Island lavas ( $\sim 40 \mathrm{~km}$ east of the ridge).

[17] Chondrite-normalized rare earth element (REE) patterns are shown in Figure 5. All samples of the active Valu Fa spreading axis and most of the seamount lavas have
$(\mathrm{La} / \mathrm{Lu})_{\mathrm{N}}$ ratios between 0.7 and 0.9 ; except some seamounts south of the ridge with $(\mathrm{La} / \mathrm{Lu})_{\mathrm{N}}=1.0-1.2$. The majority of the patterns run parallel to normal mid-ocean ridge basalt (NMORB) (Figure 5). For comparison, REE patterns of Ata Island lavas are also shown in Figure 4. They are enriched in light REE (LREE) and depleted in heavy REE (HREE) with $(\mathrm{La} / \mathrm{Lu})_{\mathrm{N}}$ ratios up to 1.7 . The REE patterns of the high-silica rocks sampled at $22^{\circ} 25^{\prime} \mathrm{S}$ are characterized by a negative $\mathrm{Eu}$ anomaly suggesting plagioclase fractionation prior to eruption.

[18] Incompatible trace element ratios, e.g., $\mathrm{Zr} / \mathrm{Nb}$ and $\mathrm{Nb} / \mathrm{Yb}$ (Figure $6 \mathrm{a}$ ) are almost constant along the spreading axis of the Valu Fa Ridge. The rhyolites at $22^{\circ} 25^{\prime} \mathrm{S}$ show slightly higher $\mathrm{Zr} / \mathrm{Nb}$ ratios which may be attributed to fractional crystallization processes [e.g., Kamber and Collerson, 2000] and lavas from the southern tip are characterized by lower $\mathrm{Nb} / \mathrm{Yb}$ ratios (see discussion below). The lavas south of the ridge are very heterogeneous covering a wide range of, e.g., $\mathrm{Zr} / \mathrm{Nb}(30-100)$ and $\mathrm{Nb} / \mathrm{Yb}(0.1-0.7$, Figure $6 \mathrm{a}) . \mathrm{Nb} / \mathrm{U}$ ratios of the Valu Fa Ridge lava series vary between 2 and 10 with a slight decrease from north to south indicating variable enrichment of $U$ relative to NMORB (Nb/U 49 [Hofmann, 1988]). Similarly, the $\mathrm{Ce} / \mathrm{Pb}$ ratios of the Valu Fa lavas are lower than those of NMORB $(\mathrm{Ce} / \mathrm{Pb} 25$ [Hofmann et al., 1986]) and show a clear decrease from 12 to 2 from the Vali Lili field to the seamounts at the southern prolongation of the ridge (Figure $6 \mathrm{~b}$ ). $\mathrm{Th} / \mathrm{Nb}$ ratios lie within 0.2 and 1.1 and thus are clearly higher than those of NMORB (Th/Nb 0.05 [Hofmann, 1988]). They are almost constant along the ridge up to the southern tip where elevated ratios are observed. The southern prolongation shows a wide range of $\mathrm{Th} / \mathrm{Nb}$ between 0.2 and 1.1 (Figure 6c).

\subsection{Radiogenic Isotope Data}

[19] Both $\mathrm{Sr}$ and $\mathrm{Nd}$ isotope ratios of the Valu Fa Ridge and seamount lavas lie within a restricted range: ${ }^{87} \mathrm{Sr} /{ }^{86} \mathrm{Sr}=$ $0.7032-0.7034,{ }^{143} \mathrm{Nd} /{ }^{144} \mathrm{Nd}=0.51301-0.51309$, with no recognizable latitudinal $\left({ }^{\circ} \mathrm{S}\right)$ variations (Figures $6 \mathrm{~d}$ and $\left.6 \mathrm{e}\right)$. The range in $\mathrm{Pb}$ isotopic composition is somewhat broader and a distinct decrease of $\mathrm{Pb}$ isotope ratios along the ridge is apparent, e.g., ${ }^{208} \mathrm{~Pb} /{ }^{204} \mathrm{~Pb}$ ratios decrease from 38.4 in the north to 38.2 at the southern prolongation of the spreading axis (Figure 6f). Notably, the Pb composition of the recently sampled Vali Lili lava is slightly less radiogenic than the lava sampled in 1990 in very close vicinity [Bach et al., 1998] (Figure 6f). On a ${ }^{208} \mathrm{~Pb} /{ }^{204} \mathrm{~Pb}$ versus ${ }^{206} \mathrm{~Pb} /{ }^{204} \mathrm{~Pb}$ isotope correlation diagram our new data plot in the field of the southern central Tonga arc and overlap with lavas from ODP Sites 834 and 839 [Ewart et al., 1994; Hergt and Hawkesworth, 1994] (Figure 6). We also note that new data plots within the Pacific rather the Indian MORB field (Figure 7).

\section{Degree of Melting and Subduction Influence}

[20] The range of major and trace element compositions covered by the Valu Fa Ridge lavas can be explained as the product of crystal fractionation processes. However, some geochemical heterogeneity along the ridge and southern prolongation suggests differences in partial melting and variable subduction influence. 


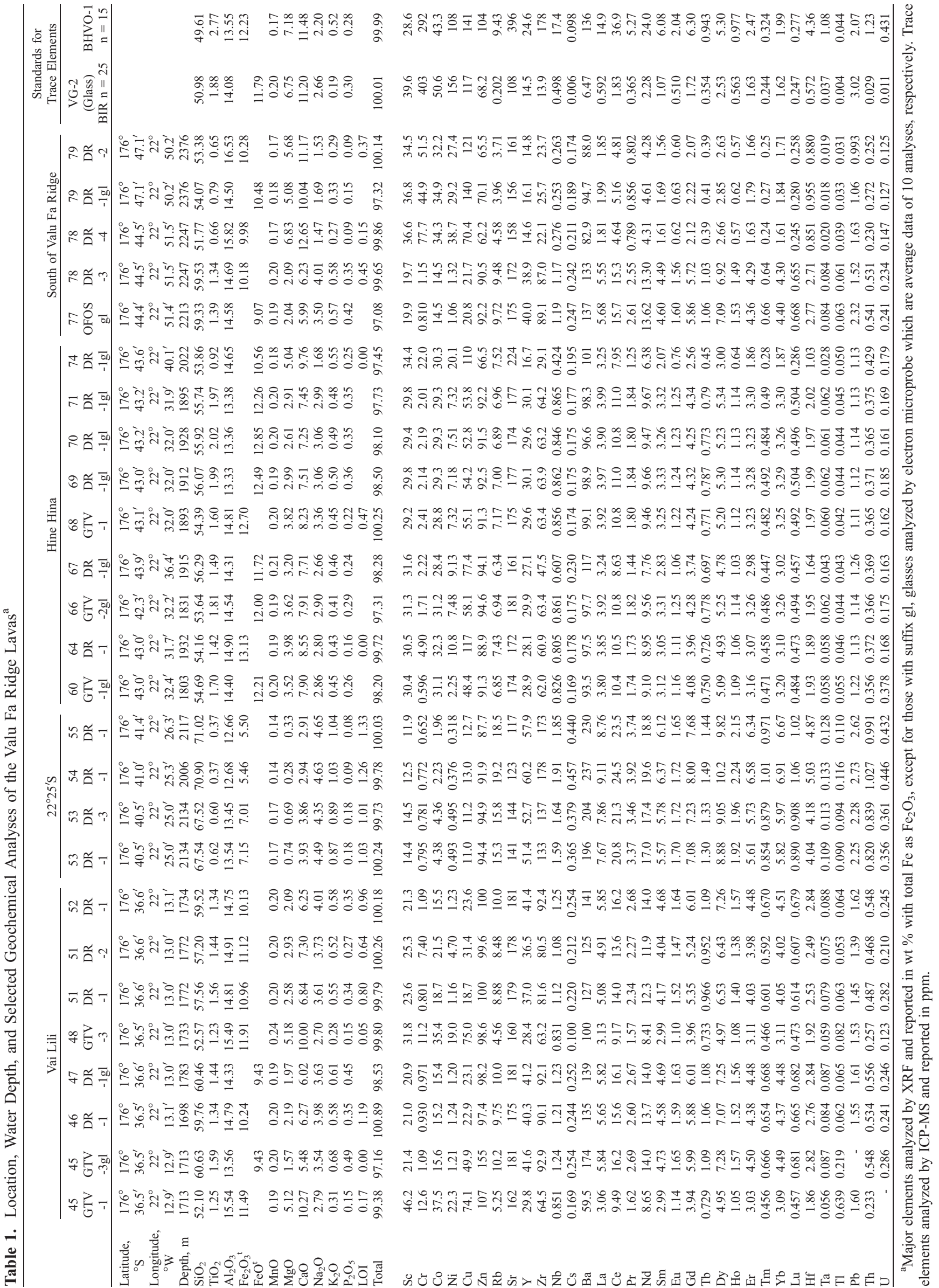

7 of 17 


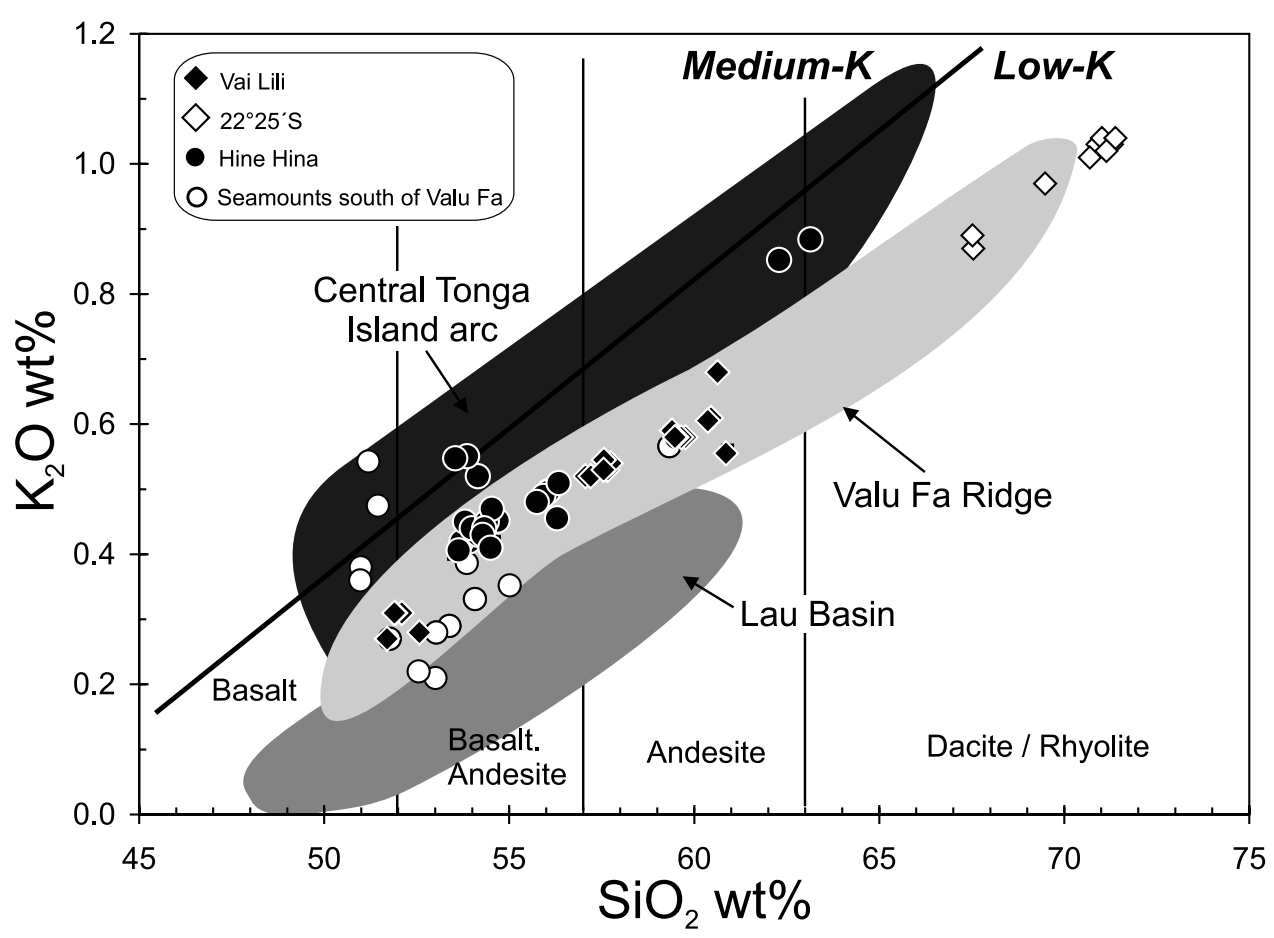

Figure 3. $\mathrm{K}_{2} \mathrm{OversusSiO}_{2}$ diagram showing Valu Fa Ridge lavas and seamounts in the southern prolongation of the ridge tip (this study). Data sources with additional Valu Fa Ridge samples, Lau Basin, and Central Tonga arc are from Hawkins and Melchior [1985], Jenner et al. [1987], Volpe et al. [1988], Boespflug et al. [1990], Frenzel et al. [1990], Sunkel, [1990], Vallier et al. [1991], Pearce et al. [1995], Turner et al. [1997], Bach et al. [1998], Peate et al. [2001]. Series boundaries and nomenclature are from Peccerillo and Taylor [1976].

[21] High degrees of partial melting as well as the loss of small melt fractions from the mantle will lead to lower $\mathrm{Nb} / \mathrm{Yb}$ ratios in volcanic rocks compared to NMORB (0.9 [Hofmann, 1988]; see Figure 6a). The $\mathrm{Nb} / \mathrm{Yb}$ depletion observed mainly in island arc lavas is the result of melt extraction during back-arc volcanism before advection into the melting regime of arc volcanism [e.g., Woodhead et al., 1993]. Pearce and Parkinson [1993] used a $\mathrm{Nb}$ versus $\mathrm{Yb}$ diagram in order to resolve partial melting from source depletion trends. The Valu Fa basalts together with lavas from Ata Island clearly fall on one trend which can be explained by different degrees of partial melting of a similar, depleted mantle source [Peate et al., 2001]. Hence $\mathrm{Nb} / \mathrm{Yb}$ ratios are potential indicators for varying degrees of melting of the mantle wedge along the Valu Fa Ridge and Ata Island. Together with the calculated $\mathrm{Na}_{8}$ values, which are inversely related with the degree of mantle melting [Klein and Langmuir, 1987], it is possible to derive assumptions about the melting processes beneath the Valu Fa Ridge, the southern prolongation, and Ata Island (representative for the central Tonga arc). The $\mathrm{Nb} / \mathrm{Yb}$ ratios along the ridge are nearly constant, but much lower than NMORB (0.9 [Hofmann, 1988]; see Figure 6a) which cannot be explained by the presence of a higher depleted mantle source alone. Assuming that NMORB is produced by $10 \%$ batch melting of a depleted mantle peridotite, we suggest that the Valu Fa lava series are generated at higher degrees of melting above $10 \%$. This is in good agreement with the degree of melting estimated for back-arc basins influenced by fluid flux from the slab [Davies and Bickle,
1991; Pfänder et al., 2002]. The region south of Hine Hina is characterized by slightly lower $\mathrm{Nb} / \mathrm{Yb}$ ratios; thus lavas are probably generated at even higher degrees of melting. The seamount lavas in the prolongation of the Valu Fa Ridge show a wide range of $\mathrm{Nb} / \mathrm{Yb}$ ratios as well as of $\mathrm{Na}_{8}$ values which probably reflects varying degrees of mantle melting (Figures 4 and 6a). Earlier studies on a small sample set of Valu Fa Ridge and Ata Island lava suggested large degrees of melting between 15 and $25 \%$ beneath the spreading axis and greater than $25 \%$ for the central Tonga arc [Peate et al., 2001]. Taking into account the variation of $\mathrm{Na}_{8}$ values along the ridge and compare those to Ata Island lavas, their degrees of melting should be slightly higher than those of the Valu Fa spreading ridge (Figure 4). The ridge tip south of Hine Hina, however, is characterized by distinctly lower $\mathrm{Nb} / \mathrm{Yb}$ ratios and low $\mathrm{Na}_{8}$ compositions implying even higher degrees of melting (Figures 4 and 6a). The most obvious explanation for such lava compositions is that fluids from the subducted slab increased the degree of melting by lowering the mantle solidus.

[22] Positive correlations between $\mathrm{H}_{2} \mathrm{O}$ and $\mathrm{U}$ have been observed in glasses from the Mariana, East Scotia Ridge, and Lau Basin [Stolper and Newman, 1994; Peate et al., 2001; Fretzdorff et al., 2002]. These studies show that U can serve as a proxy for fluid addition from the subducting slab to the magma source taking into account the potential $\mathrm{H}_{2} \mathrm{O}$ degassing in highly evolved rocks. The behavior of $\mathrm{Yb}$ in subduction zone environments is thought to be "conservative" because a significant slab contribution of this element to the magma source is mostly not detected [e.g., 


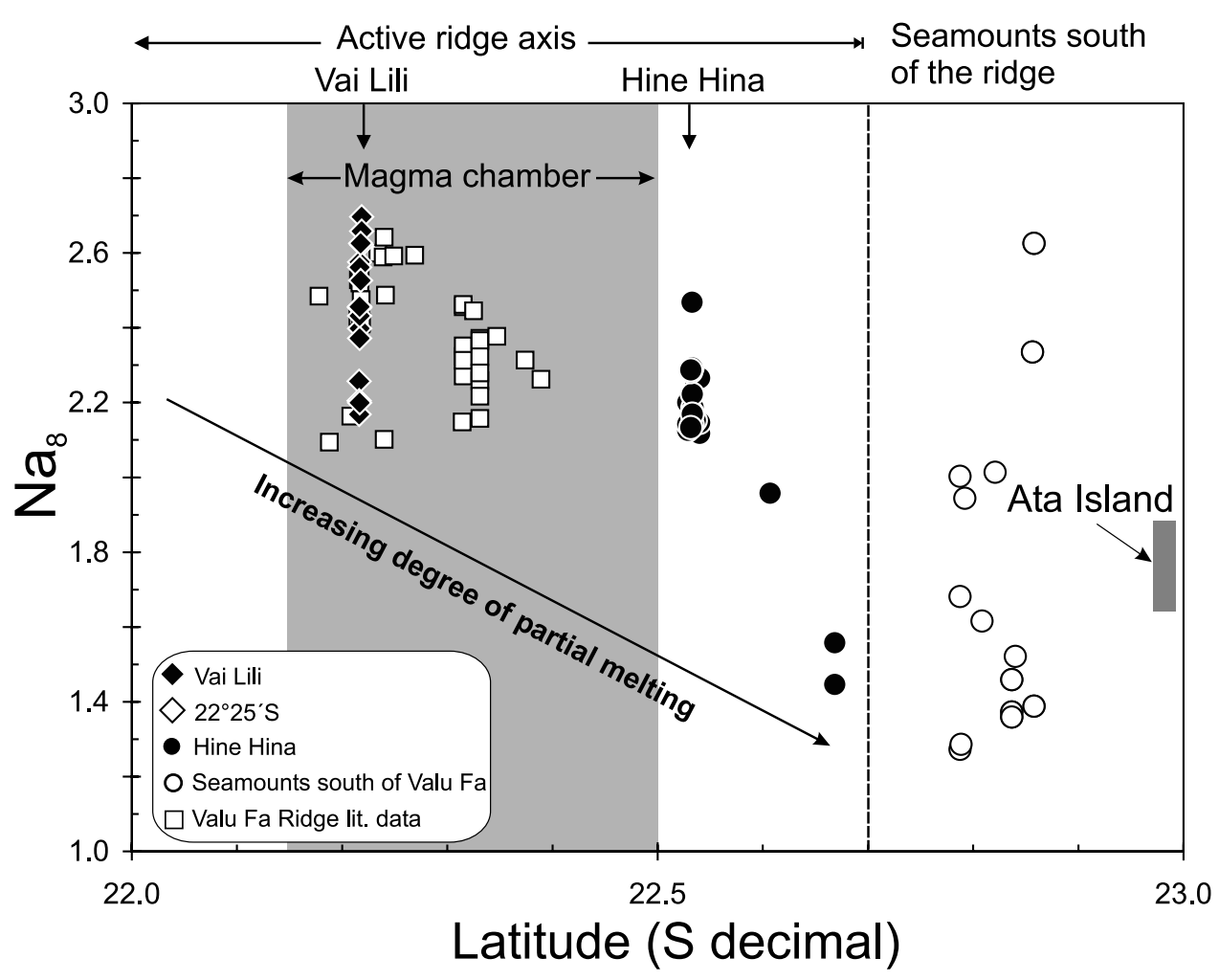

Figure 4. $\mathrm{Na}_{8}$ values calculated after Plank and Langmuir [1992] along the central and southern Valu Fa Ridge and for comparison of Ata Island. Samples with $\mathrm{MgO}$ wt \% contents below 2\% are not shown. Decreasing $\mathrm{Na}_{8}$ values indicate increasing degrees of mantle melting [e.g., Klein and Langmuir, 1987]. Data sources are as in Figure 3.

Pearce and Peate, 1995]. In the diagram $\mathrm{U}$ versus $\mathrm{Yb}$ (Figure 8), the Valu Fa Ridge and the Tonga arc lava suites display clear positive trends parallel to each other. These within-suite correlations reflect individual crystal fractionation trends with relatively primitive rocks plotting at the low ends and evolved rocks at the high ends of the arrays. The shift toward higher $\mathrm{U}$ for a given $\mathrm{Yb}$ concentration suggests variable contributions from a fluid component, with Lau Basin samples showing the lowest and Tonga arc rocks the highest influence (Figure 8). Volcanic rocks from the southern tip and the southern prolongation of the Valu Fa spreading axis show elevated U concentrations indicating higher fluid contribution from the subducting slab compared to the rest of the Valu Fa lava suite (Figure 8). Similarly, these lavas have high $\mathrm{Ce} / \mathrm{Pb}$ ratios (Figure $6 \mathrm{~b}$ ), since $\mathrm{Pb}$ is highly mobile in fluids relative to $\mathrm{Ce}$ [e.g., Miller et al., 1994], this supports our assumption of a high fluid flux beneath the southern ridge tip, hence higher degrees of partial melting at the southern tip of the spreading axis due to fluid contributions from the subducting slab. The distinct decrease in $\mathrm{Ce} / \mathrm{Pb}$ ratios along the Valu Fa Ridge spreading axis from north to south indicates the preferential addition of $\mathrm{Pb}$ toward the south. Such a slab-derived fluid may also consist of variable components, derived from dehydration of basaltic crust and from dewatering of sediments [Ishikawa and Tera, 1999; Class et al., 2000]. Surprisingly, this distinct trend along the back-arc ridge is neither correlated with incompatible trace element ratios indicating varying degrees of partial melting nor with the $\mathrm{Na}_{8}$ compositions. Since $\mathrm{Pb}$ is extremely soluble in hydrous fluids [Keppler, 1996], a possible explanation for the observed discrepancy is that the added amount of a fluid component is too low to influence the mantle solidus but has a visible effect on the $\mathrm{Pb}$ concentrations and $\mathrm{Pb}$ isotope ratios (see also Figures $6 \mathrm{~b}$ and 7 ). The input of $\mathrm{Pb}$ by a sediment melt would also not lead to significantly higher degrees of partial melting [e.g., Class et al., 2000], but a sediment component should lower, for example, the ${ }^{144} \mathrm{Nd} /{ }^{143} \mathrm{Nd}$ ratios (e.g., average south Pacific sediment from DSDP 204, 0.51265 [Ewart et al., 1998]). However, there is no evidence for a sediment "fingerprint" in the $\mathrm{Nd}$ isotopic composition of the Valu Fa and Ata Island lavas (Figure 6e), thus the $\mathrm{Pb}$ component was most likely not carried with a sediment melt. Another explanation for the $\mathrm{Pb}$ along-axis variation is the presence of a heterogeneous mantle source beneath the Valu Fa Ridge which will be discussed below (see section 8).

\section{Comparison With Other Propagating Rifts, i.e., the North Fiji Basin}

[23] The tip of the propagating North Fiji back-arc basin is characterized by relatively low degrees of melting ( $\sim 16 \%)$, whereas in the central part of the basin the melting starts deeper and reaches a higher rate (up to $22 \%$ ), based on dynamic partial melting of a thermally heterogeneous rising mantle at different depths [Fleutelot et $a l ., 2005]$. This is in agreement with petrogenetic processes 

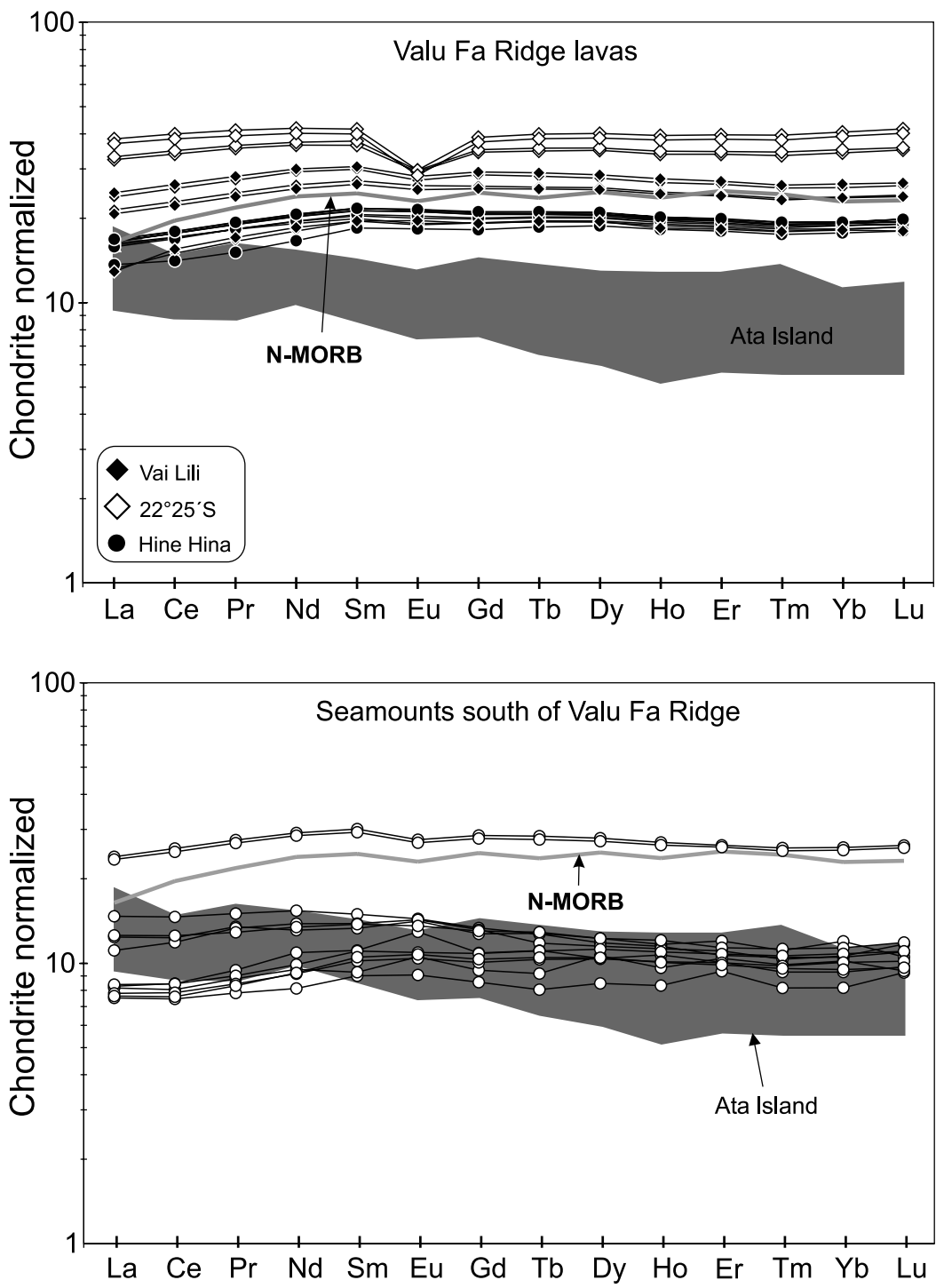

Figure 5. Chondrite normalized [Sun and McDonough, 1989] rare earth element (REE) patterns of the Valu Fa Ridge lavas, NMORB [Hofmann, 1988], and for comparison of Ata Island volcanic rocks [Turner et al., 1997].

at propagating mid-ocean ridge spreading centers such as at Galapagos and Juan de Fuca. Thus Fleutelot et al. [2005] suggest that magmatic processes along propagating backarc and mid-ocean ridge spreading centers are comparable. However, our studies show high degrees of mantle melting beneath the propagating ridge tip whereas the lavas erupted at the center of the Valu Fa Ridge have been generated at considerably lower degrees. Consequently, the observation of Fleutelot et al. [2005] seems not valid for all oceanic back-arc basins. The influence of subduction, related to proximity to the volcanic front, is also important. However, similarities between other propagating ocean ridges and the Valu Fa Ridge include the occurrence of extensive crystal fractionation processes about $30 \mathrm{~km}$ behind the rift tip. This is in accordance with the observation of Sinton et al. [1983] suggesting that the maximum of differentiation proceeds within $50 \mathrm{~km}$ behind propagating ridge tips. A well studied example is the North Fiji Basin, where the eruption of the most differentiated lavas occurred some $20 \mathrm{~km}$ behind the propagating rift tip [Fleutelot et al., 2005]. Interestingly, the Valu Fa Ridge lavas are characterized by highly variable degrees of differentiation (between 50 and $70 \mathrm{SiO}_{2}$ wt \%), even along the seismically imaged magma chamber area. Magma replenishment models have been carried out and tested on the north-south propagating North Fiji Basin [Caroff and Fleutelot, 2003]. In the model, the magma migrates through different open system reservoirs along the propagating segment ending up in a closed system reservoir. Mafic and intermediate lava erupted from a periodically replenished magma chamber system, while the more differentiated lava generated in a closed system reservoir, located at the termination of the propagating segment. Hence the differentiation variations along Valu Fa Ridge may be related to the presence of interconnected magma chambers and a closed system reservoir where the highly evolved magma was generated. This magma body is 

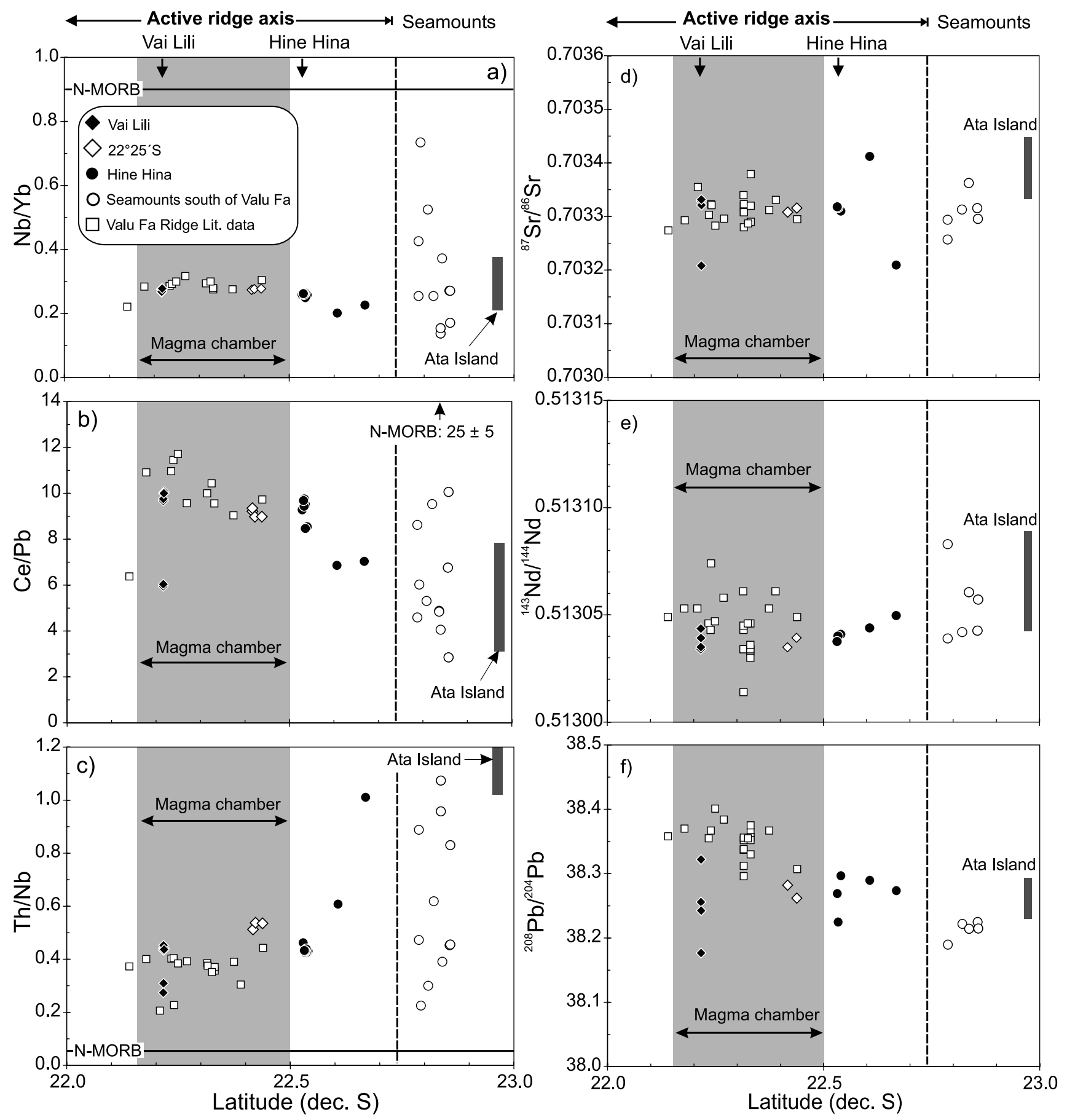

Figure 6. (a) $\mathrm{Nb} / \mathrm{Yb}$; (b) $\mathrm{Ce} / \mathrm{Pb}$; (c) $\mathrm{Th} / \mathrm{Nb}$; (d) ${ }^{87} \mathrm{Sr} /{ }^{86} \mathrm{Sr}$; (e) ${ }^{143} \mathrm{Nd} /{ }^{144} \mathrm{Nd}$; (f) ${ }^{208} \mathrm{~Pb} /{ }^{204} \mathrm{~Pb}$ variations along the central and southern Valu Fa Ridge. The extension of the magma chamber is estimated after Day et al. [2001]. For comparison, compositions of volcanic rocks from Ata Island, which is located $\sim 40 \mathrm{~km}$ west of the back-arc basin, are also plotted [Turner et al., 1997]. In Figure 6c, NMORB composition is taken from Hofmann [1988] and Hofmann et al. [1986]. Errors $(2 \sigma)$ of the radiogenic isotope ratios lie within the symbol size. Data sources are this study, Boesflug et al. [1990], Loock et al. [1990], Turner et al. [1997], Bach et al. [1998], and Peate et al. [2001]. 

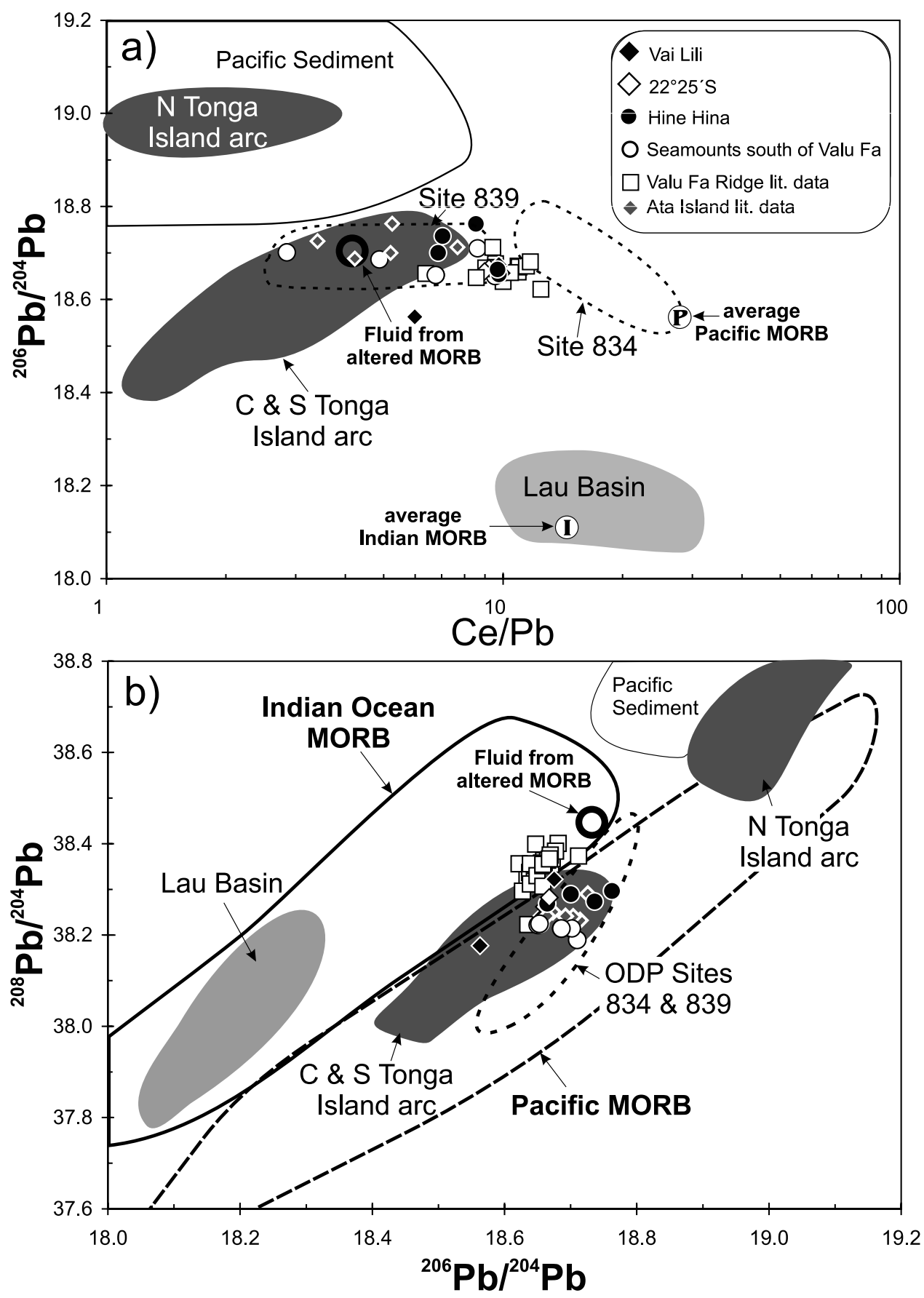

Figure 7. (a) The ${ }^{208} \mathrm{~Pb} /{ }^{204} \mathrm{~Pb}$ versus $\mathrm{Ce} / \mathrm{Pb}$ and (b) ${ }^{208} \mathrm{~Pb} /{ }^{204} \mathrm{~Pb}$ versus ${ }^{206} \mathrm{~Pb} /{ }^{204} \mathrm{~Pb}$ ratios for volcanic rocks of Valu Fa Ridge and southern prolongation, the Lau Basin, Tonga arc, ODP sites 834 and 839. Pacific sediment and altered oceanic crust fluid composition after Haase et al. [2002] and Peate et al. [2001] is also plotted in both diagrams. In Figure 7a, average compositions of Indian Ocean and Pacific MORB are from Sims and DePaolo [1997] for Ce/Pb ratios and Hergt and Hawkesworth [1994] for ${ }^{208} \mathrm{~Pb} /{ }^{204} \mathrm{~Pb}$. Errors $(2 \sigma)$ lie within the symbol size. Data sources are as in Figure 6, and Pacific sediment after Ewart et al. [1998]; Indian Ocean and Pacific MORB after Ito et al. [1987], Mahoney et al. [1989], Prinzhofer et al. [1989], Ewart et al. [1994], Mahoney et al. [1994], Bach et al. [1996], and Vlastelic et al. [1999]; and ODP sites after Hergt and Farley [1994] and Ewart et al. [1994]. 


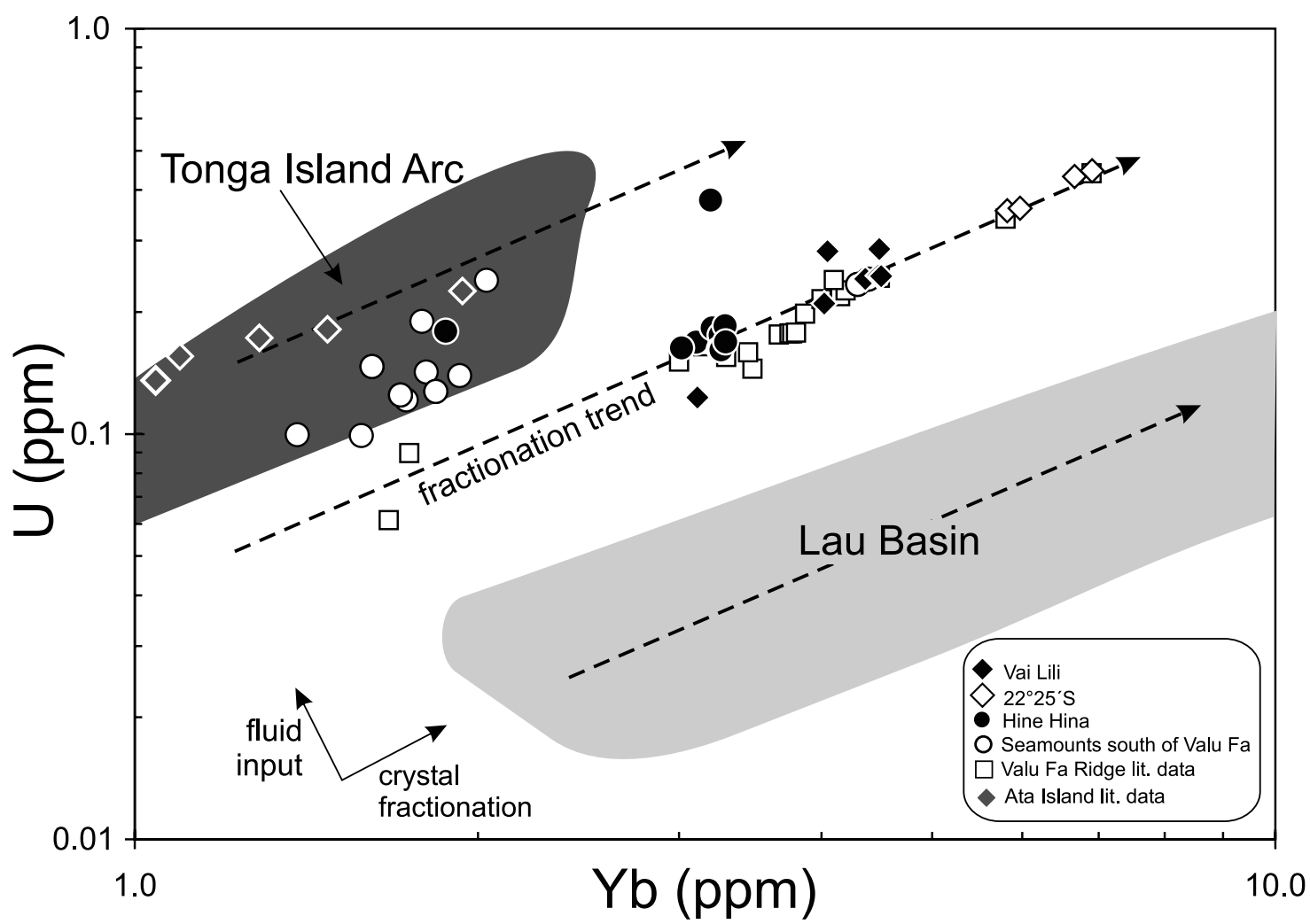

Figure 8. $\mathrm{U}(\mathrm{ppm})$ versus $\mathrm{Yb}(\mathrm{ppm})$ concentrations of the Valu Fa Ridge lavas and seamounts in the southern prolongation of the ridge tip (this study). For comparison, Lau Basin and Tonga arc volcanic rocks are also shown (data sources as in Figures 3 and 6).

located at the southern end of the seismically imaged magma chamber near the southern end of the propagating ridge.

[24] The extensive crystal fractionation (Figure 3), the highly structured and tectonically active state at segment V7 strongly suggest a large potential for hydrothermal circulation. The sampled area, however, does not show any indication for recent hydrothermal activity.

\section{Mantle Source-Mantle Flow}

[25] Hergt and Hawkesworth [1994] suggested a southward displacement of an Indian Ocean MORB by Pacifictype mantle on the Lau Basin as a result of slab rollback, accompanied by the southward migration of the Valu $\mathrm{Fa}$ Ridge into island arc crust. Furthermore, lavas erupted along the Havre Trough between $24^{\circ}$ and $29^{\circ} \mathrm{S}$ have Pacific MORB isotopic character and support the model in which Indian-type replaces Pacific-type mantle in the region north of Havre Trough [Haase et al., 2002]. Indeed, isotopic composition of the central and eastern Lau Basin implies that the magma source is very similar to Indian Ocean MORB-type, whereas the mantle source beneath Valu Fa Ridge is characterized by a Pacific-type signature [e.g., Loock et al., 1990; Peate et al., 2001] (Figure 7a). In contrast, $\mathrm{Pb}$ isotope signatures of samples from the northern part of the Valu Fa Ridge are clearly associated with the Indian Ocean MORB field (Figure 7b). Haase et al. [2002] studied the magma generation processes and mantle dynamics along the Kermadec Arc-Havre Trough comparing them to those of the Tonga arc and Lau Basin. On the basis of end-member composition modeling, they have calculated a possible fluid composition from the altered oceanic crust with elevated ${ }^{208} \mathrm{~Pb} /{ }^{204} \mathrm{~Pb}$ ratios of 38.4 (Figure $7 \mathrm{~b}$ ). Additions of such a fluid probably have influenced the northern Valu Fa Ridge samples and "push" them into the Indian Ocean MORB field, i.e., overprint their Pacific MORB signature. Mass balance calculations of Bach et al. [1998] suggest that the northern Valu Fa lavas are influenced by a significant addition of subducted altered oceanic crust and subordinate by sediment melt. Our samples have relatively unradiogenic ${ }^{208} \mathrm{~Pb} /{ }^{204} \mathrm{~Pb}$ ratios that plot well within the Pacific MORB field (Figure 7b). Both, trace element ratios and isotopic composition from the southern part of the Valu Fa Ridge and southern seamounts resemble very closely those of the volcanic rocks from ODP Site 839, located west of the Eastern Lau Basin [Ewart et al., 1994] (Figure 7). This lava sequence is interpreted to reflect an older remnant of a "protocentral Tonga arc" crust and is compositionally very similar to the active central and southern Tonga arc [Ewart et al., 1994] (Figure 7). The Pb isotopic composition of lavas from the southern part of the Valu Fa Ridge implies that this part is underlain by the same Pacific-type mantle wedge source generating the basalts from the ODP site 839 and feeding the central and southern Tonga arc volcanoes. The latter are dominated by partial melting of the mantle wedge with addition of fluids from the dehydrating altered oceanic crust and minor contributions from the subducted sediments [Turner and Hawkesworth, 1997; Turner et al., 1997]. The sediment addition is less than $0.5 \%$ and takes 
place as small degree partial melts in equilibrium with ilmenite and rutile, based on the very low concentrations of $\mathrm{Ta}$ and $\mathrm{Nb}$ [Turner et al., 1997].

[26] Our results show that the transition from spreading to propagating rifting, hence the compositional change of the mantle wedge, is most likely located south of the Hine Hina field, in the vicinity of $22^{\circ} 35^{\prime} \mathrm{S}$, evidenced by the decrease in $\mathrm{Ce} / \mathrm{Pb}$, increase of $\mathrm{Th} / \mathrm{Nb}$ ratios, and elevated $\mathrm{U}$ ppm concentration (Figure 6c, 7a, and 8). Notably, lavas erupted at Vai Lili show "bimodal" compositions for their ${ }^{87} \mathrm{Sr} /{ }^{86} \mathrm{Sr}$, ${ }^{208} \mathrm{~Pb} /{ }^{204} \mathrm{~Pb}$ and $\mathrm{Ce} / \mathrm{Pb}$ ratios, probably due to different eruption ages. The younger lavas that cover most of the Vai Lili vent field (see chapter 3.1), show high ${ }^{208} \mathrm{~Pb} /{ }^{204} \mathrm{~Pb}$ and therefore represent the active spreading phase. The rocks that are similar in composition to the Tonga arc likely reflect an older rifting phase.

\section{Conclusions}

[27] 1. Detailed bathymetric maps of the central and southern Valu Fa Ridge show a rather flat topography, comparable to fast spreading mid-ocean ridges. To the south, the ridge evolves into a system of tectonic half graben and graben.

[28] 2. Vai Lili field is characterized by a revival of volcanism with lava flows erupted after 1993 covering most of the hydrothermal vent field. Ongoing hydrothermal activity at the former Vai Lili site was only recorded by diffuse low-temperature discharge.

[29] 3. Several small explosive and hydrovolcanic eruptions took place at the Hine Hina vent field. Hydrothermal activity continued after the eruptions evidenced by a thermal anomaly between $0.05^{\circ} \mathrm{C}$ and $0.22^{\circ} \mathrm{C}$ in the overlying water column, shimmering water and white-yellow biological mats found during our survey.

[30] 4. The striking topographic high with a deep graben structure observed at the southern rift fault zone at $22^{\circ} 51^{\prime} \mathrm{S}$ may be related to magmatic doming which would suggest that this structure is the actively southward propagating Valu Fa rift system close to the Tonga arc.

[31] 5. Valu Fa Ridge samples range from basaltic andesite to rhyolite with $\mathrm{SiO}_{2}$ contents up to $72 \mathrm{wt} \%$. The maximum of differentiation took place about $30 \mathrm{~km}$ behind the propagating Valu Fa ridge tip, hence fits into the general models of crystal fractionation processes along propagating spreading ridges. Lava with primitive to intermediate character erupted from interconnected periodically replenished magma chambers, while the highly differentiated lava generated in a closed system reservoir, located at the southern end of the seismically imaged magma chamber near the southern termination of the propagating ridge.

[32] 6. Although the eruption of highly fractionated lavas at $25^{\circ} 25^{\prime} \mathrm{S}$ points to a site of ongoing hydrothermal activity as it is the case for other of hydrothermal fields [Perfit et al., 1999], our survey did not reveal any signs of ongoing hydrothermal activity or thermal anomalies in the overlying water column. The highly structured and tectonically active state at segment V7, however, strongly suggest a large potential for hydrothermal circulation.

[33] 7. The degrees of melting beneath the studied area are 5 to $10 \%$ higher than reported for NMORB, volcanic rocks from the southern tip of the ridge show degrees of melting above $25 \%$. The seamounts at the southern prolongation of the ridge are characterized by variable degrees of melting, probably in the range of 15 to $25 \%$.

[34] 8. The striking topographic high with a deep graben structure observed at the southern rift fault zone at $22^{\circ} 51^{\prime} \mathrm{S}$ may be related to magmatic doming which would suggest that this structure is the actively southward propagating Valu Fa rift system close to the Tonga arc.

[35] 9. Radiogenic isotope ratios of lava erupted south of the Hine Hina field are similar to those of the ODP Site 839, located west of the Eastern Lau Basin representing old island arc crust. Thus we suggest that the transition from spreading to propagating rifting, i.e., the compositional change of the mantle wedge is located in the vicinity of $22^{\circ} 35^{\prime} \mathrm{S}$.

\section{Appendix A: Analytical Techniques}

[36] Where possible, fresh glass chips were separated from lava blocks, washed several times with deionized water and picked under a binolcular microscope. The major element compositions of the glasses were determined on a JEOL JXA 8900R electron microprobe at Kiel University. This instrument operates with a $10 \mu \mathrm{m}$ defocused beam, a $10 \mathrm{nA}$ beam current, a $15 \mathrm{kV}$ acceleration voltage and is calibrated against natural glass standards. Precision and accuracy relative to VG-2 were both better than $1 \%(2 \sigma)$ for all major elements. Subsets of glass fragments were ground to powder in an agate mortar and used for trace element and isotope analyses. Cores of the freshest whole rock material were cut, coarse crushed, thoroughly washed in deionized water, and then milled to a fine powder in an agate mortar. For major element determinations, 0.6 grams of powder was mixed with lithium tetraborate and ammonium nitrate, fused to a homogeneous glass bead, and analyzed using a Philips PW1400 XRF spectrometer (Universität Kiel) equipped with a Rh tube and calibrated against international rock standards (Table 1 ). Precision $(2 \sigma)$ for most major elements was better than $1 \%$, with exceptions being $\mathrm{TiO}_{2}, \mathrm{Na}_{2} \mathrm{O}$ and $\mathrm{P}_{2} \mathrm{O}_{5}(\sim 5 \%)$, and accuracy relative to VG-2 was better than $1 \%$ (Table 1). Loss on ignition was determined by weight loss of $3 \mathrm{~g}$ of powder heated to $1000^{\circ} \mathrm{C}$ for 2 hours in a silica crucible.

[37] Concentrations of 33 trace elements were determined by ICP mass spectrometry after pressurized HF-aqua regia digestion of approximately $100 \mathrm{mg}$ pulverized sample, made up to a solution with $<0.1 \%$ total dissolved solids in subboiled $2 \%(\mathrm{v} / \mathrm{v})$ nitric acid. Prior to analysis, sample digest solutions were tenfold diluted and spiked with $5 \mathrm{ng} / \mathrm{mL}$ indium (In) and rhenium (Re) for internal standardization. The instrument was calibrated using aqueous multielement calibration standards without further matrix matching. All measurements were done using an Agilent 7500c ICP-MS instrument under standard operating conditions with plasma shield on, but no gas in the octopole reaction cell. Sample solution was introduced using a selfaspirating PFA micronebulizer $(100 \mu \mathrm{l} / \mathrm{min}$ sample uptake $)$ in combination with a standard Scott-type spray chamber maintained at $4^{\circ} \mathrm{C}$. The analytical results represent averages of three replicate measurements after subtraction of a laboratory reagent blank. For analytical quality control procedural blanks ("Blank") and international reference 
Table A1. Sr-Nd-Pb Isotope Ratios of Selected Valu Fa Ridge Lavas ${ }^{\text {a }}$

\begin{tabular}{|c|c|c|c|c|c|c|c|c|c|c|}
\hline Sample & ${ }^{87} \mathrm{Sr} /{ }^{86} \mathrm{Sr}^{\mathrm{a}}$ & $2 \sigma$ & ${ }^{143} \mathrm{Nd} /{ }^{144} \mathrm{Nd}$ & $2 \sigma$ & ${ }^{206} \mathrm{~Pb} /{ }^{204} \mathrm{~Pb}$ & $2 \sigma$ & ${ }^{207} \mathrm{~Pb} /{ }^{204} \mathrm{~Pb}$ & $2 \sigma$ & ${ }^{208} \mathrm{~Pb} /{ }^{204} \mathrm{~Pb}$ & $2 \sigma$ \\
\hline \multicolumn{11}{|c|}{ Vai Lili } \\
\hline 47DR-1gl & 0.703321 & 3 & 0.513039 & 2 & 18.657 & 0.001 & 15.527 & 0.000 & 38.242 & 0.001 \\
\hline 48GTV-3 & 0.703208 & 3 & 0.513035 & 2 & 18.563 & 0.001 & 15.520 & 0.001 & 38.177 & 0.004 \\
\hline 51DR-2 & 0.703330 & 3 & 0.513044 & 2 & 18.675 & 0.002 & 15.551 & 0.002 & 38.322 & 0.007 \\
\hline \multicolumn{11}{|c|}{$22^{\circ} 25^{\prime} S$} \\
\hline $55 \mathrm{DR}-1$ & 0.703316 & 2 & 0.513039 & 2 & 18.660 & 0.001 & 15.532 & 0.001 & 38.262 & 0.002 \\
\hline \multicolumn{11}{|c|}{ Hine Hina } \\
\hline 60GTV-1gl & 0.703310 & 2 & 0.513041 & 3 & 18.762 & 0.003 & 15.529 & 0.002 & 38.297 & 0.006 \\
\hline 67DR-1gl & 0.703412 & 2 & 0.513044 & 3 & 18.700 & 0.002 & 15.538 & 0.002 & 38.290 & 0.005 \\
\hline 69DR-1gl & 0.703317 & 2 & 0.513040 & 2 & 18.654 & 0.001 & 15.521 & 0.001 & 38.225 & 0.002 \\
\hline 71DR-1g1 & 0.703318 & 2 & 0.513038 & 3 & 18.665 & 0.001 & 15.534 & 0.001 & 38.269 & 0.004 \\
\hline 74DR-1gl & 0.703209 & 2 & 0.513050 & 2 & 18.736 & 0.001 & 15.532 & 0.001 & 38.274 & 0.002 \\
\hline \multicolumn{11}{|c|}{ South of Valu Fa Ridge } \\
\hline 77OFOS gl & 0.703316 & 2 & 0.513043 & 3 & 18.653 & 0.001 & 15.522 & 0.001 & 38.225 & 0.002 \\
\hline 78DR-4 & 0.703296 & 3 & 0.513057 & 2 & 18.701 & 0.001 & 15.528 & 0.001 & 38.215 & 0.002 \\
\hline 79DR-1gl & 0.703362 & 3 & 0.513061 & 2 & 18.686 & 0.001 & 15.532 & 0.001 & 38.214 & 0.002 \\
\hline
\end{tabular}

${ }^{\mathrm{a}}$ Isotope ratios for Sr normalized to NBS $987\left({ }^{87} \mathrm{Sr} /{ }^{86} \mathrm{Sr}=0.71025\right)$ and for Pb to NBS 981 [Todt et al., 1996]. Errors $2 \sigma$ standard errors of the mean and referring to in-run statistics.

standards were prepared and analyzed along with the sample series. Results for the international rock standards BIR and BHVO-1 (both from U.S. Geological Survey; see suggested values of Jenner et al. [1990] and Govindaraju [1994] are reported in Table 1. Standards and three samples were digested in duplicate yielding differences of the results well below $1-3 \%$ relating to all elements. Instrument stability was monitored by reanalyzing one sample every 11 samples, and precision as calculated from 6 replicate analyses covering 27 hours was $<1-2 \%$ RSD for all elements. Further details of the sample preparation procedure and instrument calibration strategy are given by Garbe-Schönberg [1993].

[38] $\mathrm{Sr}, \mathrm{Nd}, \mathrm{Pb}$ isotopic compositions are shown in Table A1 and were determined in static mode on the TRITON and MAT $262 \mathrm{RPQ}^{2+}$ thermal ionization mass spectrometers (TIMS) at IFM-GEOMAR. Prior to dissolution, samples were leached for 1 hour in hot $6 \mathrm{~N} \mathrm{HCl}$ (powders) and $3 \mathrm{~N}$ $\mathrm{HCl}$ (glass chips) and thereafter repeatedly rinsed with 18.2 $\mathrm{M} \Omega$ water. Sample chromatography followed Hoernle and Tilton [1991]. Applied isotope fractionation corrections are ${ }^{86} \mathrm{Sr}{ }^{88} \mathrm{Sr}=0.1194$ and ${ }^{146} \mathrm{Nd} /{ }^{144} \mathrm{Nd}=0.7219$, with all errors reported as $2 \sigma$ standard errors of the mean. Analyses of NBS 987 over the course of this study yielded ${ }^{87} \mathrm{Sr} /{ }^{86} \mathrm{Sr}=$ $0.710261 \pm 10(\mathrm{n}=5)$ and sample values are reported relative to ${ }^{87} \mathrm{Sr} /{ }^{86} \mathrm{Sr}=0.71025$ for NBS 987. The in-house $\mathrm{Nd}$ monitor SPEX gave ${ }^{143} \mathrm{Nd} /{ }^{144} \mathrm{Nd}=0.511714 \pm 4[\mathrm{n}=3]$ and has been previously calibrated with ${ }^{143} \mathrm{Nd} /{ }^{144} \mathrm{Nd}=$ $0.511706 \pm 12(\mathrm{n}=10)$ against La Jolla at ${ }^{143} \mathrm{Nd} /{ }^{144} \mathrm{Nd}=$ $0.511848 \pm 8(\mathrm{n}=10)$. A mass bias correction of $\sim 0.11 \% /$ amu is applied to the $\mathrm{Pb}$ isotope data based on repeated measurements of NBS $981\left(\mathrm{n}=6 ;{ }^{206} \mathrm{~Pb} /{ }^{204} \mathrm{~Pb}=16.904 \pm 9\right.$, $\left.{ }^{207} \mathrm{~Pb} /{ }^{204} \mathrm{~Pb}=15.443 \pm 11,{ }^{208} \mathrm{~Pb} /{ }^{204} \mathrm{~Pb}=36.545 \pm 36\right)$ and normalization to the NBS 981 values reported by Todt et al. [1996]. Total chemistry $\mathrm{Pb}$ blanks were typically below $100 \mathrm{pg}$ and thus considered negligible.

[39] Acknowledgments. We thank Captain Kull, crew and shipboard scientific party of R/V Sonne cruise SO167 for their expertise and help during the sampling program. Many thanks to P. Appel, B. Mader, and A. Weinkauf for assistance with the major element analyses. P. Leat, I. J. Graham, and G. Massoth are gratefully acknowledged for their constructive reviews. This work was funded by the Bundesministerium für Bildung und Forschung (BMBF grant 03GO167A and B).

\section{References}

Bach, W., J. Erzinger, L. Dosso, J. Bollinger, H. Bougault, J. Etoubleau, and J. Sauerwein (1996), Unusually large Nb-Ta depletions in North Chile ridge basalts at $36^{\circ} 50^{\prime}$ to $38^{\circ} 56^{\prime} \mathrm{S}$ : Major element, trace element, and isotopic data, Earth Planet. Sci. Lett., 142, 223-240.

Bach, W., E. Hegner, and J. Erzinger (1998), Chemical fluxes in the Tonga subduction zone: Evidence from the southern Lau Basin, Geophys. Res. Lett., 25, 1467-1470

Baker, E. T., G. J. Massoth, K. Nakamura, R. W. Embly, C. E. J. de Ronde, and R. J. Arculus (2005), Hydrothermal activity on near-arc sections of back-arc ridges: Results from the Mariana Trough and Lau Basin, Geochem. Geophys. Geosyst., 6, Q09001, doi:10.1029/2005GC000948.

Bevis, M., et al. (1995), Geodetic observations of very rapid convergence and back-arc extension at the Tonga Arc, Nature, 374, 249-251.

Boespflug, X., L. Dosso, and H. Bougart (1990), Trace element and isotopic ( $\mathrm{Sr}, \mathrm{Nd})$ geochemistry of volcanic rocks from the Lau Basin, Geol. Jahrb., Reihe D, 92, 503-516.

Caroff, M., and C. Fleutelot (2003), The north-south propagating spreading center of the North Fiji Basin: Modeling of the geochemical evolution in periodically replenished and tapped magma chambers, Minerol. Petrol., $79,203-224$

Class, C., D. M. Miller, and C. H. Langmuir (2000), Distinguishing melt and fluid subduction components in Umnak Volcanics, Aleutian Arc, Geochem. Geophys. Geosyst., 1(6), doi:10.1029/1999GC000010.

Collier, J., and M. Sinha (1990), Seismic images of a magma chamber beneath the Lau Basin back-arc spreading centre, Nature, 346, 646648

Collier, J. S., and M. C. Sinha (1992), Seismic mapping of a magma chamber beneath the Valu Fa Ridge, Lau Basin, J. Geophys. Res., 97(B10), 14,031-14,053

Davies, J. H., and M. J. Bickle (1991), A physical model for the volume and composition of melt produced by hydrous fluxing above subduction zones, Philos. Trans. R. Soc. London, 335, 355-364.

Day, A. J., C. Peirce, and M. C. Sinha (2001), Three-dimensional crustal structure and magma chamber geometry at the intermediate-spreading, back-arc Valu Fa Ridge, Lau Basin: Results of a wide-angle seismic tomographic inversion, Geophys. J. Int., 146, 31-52.

Detrick, R. S., P. Buhl, E. E. Vera, J. C. Mutter, J. A. Orcutt, J. A. Madsen, and T. M. Brocher (1987), Multi-channel seismic imaging of a crustal magma chamber along the East Pacific Rise, Nature, 326, 35-41.

Ewart, A., J. M. Hergt, and J. W. Hawkins (1994), Major element, trace element, and isotope $(\mathrm{Pb}, \mathrm{Sr}$, and $\mathrm{Nd})$ geochemistry of Site 839 basalts and basaltic andesites: Implications for arc volcanism, Proc. Ocean Drill. Program Sci. Results, 135, 519-531. 
Ewart, A., K. D. Collerson, M. Regelous, J. I. Wendt, and Y. Niu (1998), Geochemical evolution within the Tonga-Kermadec-Lau Arc-Back-arc systems: The role of varying mantle wedge composition in space and time, J. Petrol., 39, 331-368.

Falloon, T. J., D. H. Green, C. J. Hatton, and K. L. Harris (1988), Anhydrous partial melting of a fertile and depleted peridotite from 2 to $30 \mathrm{~Kb}$ and application to basalt petrogenesis, J. Petrol., 29, 1257-1282.

Fleutelot, C., J.-P. Eissen, L. Dosso, T. Juteau, P. Launeau, C. Bollinger, J. Cotten, L. V. Danyushevsky, and L. Savoyant (2005), Petrogenetic variability along the north-south propagating spreading center of the North Fiji Basin, Mineral. Petrol., 83, 55-86.

Fouquet, Y., U. von Stackelberg, and R. K. Mühe (1989), Intense hydrothermal activity in a back arc environment: Lau Basin SW Pacific: Results from French-German cruise with Nautile, Eos Trans. AGU, 70(43), 1383.

Fouquet, Y., et al. (1991), Hydrothermal activity and metallogenesis in the Lau back-arc basin, Nature, 349, 778-781.

Fouquet, Y., U. von Stackelberg, J. L. Charlou, J. Erzinger, P. Herzig, R. Mühe, and M. Wiedicke (1993), Metallogenesis in back arc environments. The Lau Basin example, Econ. Geol., 88, 2154-2181.

Frenzel, G., R. Mühe, and P. Stoffers (1990), Petrology of the volcanic rocks from the Lau Basin, southwest Pacific, Geol. Jahrb., Reihe D, 92, 395-479

Fretzdorff, S., R. A. Livermore, C. W. Devey, P. T. Leat, and P. Stoffers (2002), Petrogenesis of the back-arc East Scotia Ridge, South Atlantic Ocean, J. Petrol., 43, 1435-1467.

Garbe-Schönberg, C.-D. (1993), Simultaneous determination of thirtyseven trace elements in twenty-eight international rock standards by ICP-MS, Geostand. Newsl, 17, 81-97.

Govindaraju, K. (1994), Compilation of working values and sampledescription for 383 geostandards, Geostand. Newsl., 13, 1-158.

Haase, K. M., T. J. Worthington, P. Stoffers, D. Garbe-Schönberg, and I. Wright (2002), Mantle dynamics, element recycling, and magma genesis beneath the Kermadec Arc-Havre Trough, Geochem. Geophys. Geosyst., 3(11), 1071, doi:10.1029/2002GC000335.

Hawkins, J. W. (1995a), Evolution of the Lau Basin: Insights from ODP Leg 135, in Active Margins and Marginal Basins of the Western Pacific, Geophys. Monogr. Ser., vol. 88, edited by B. Taylor and J. Natland, pp. 125-173, AGU, Washington, D. C

Hawkins, J. W. (1995b), The geology of the Lau Basin, in Backarc Basins. Tectonics and Magmatism, edited by B. Taylor, pp. 63-138, Springer, New York.

Hawkins, J. W., and J. T. Melchior (1985), Petrology of Mariana Trough and Lau Basin basalts, J. Geophys. Res., 90, 11,431-11,468.

Hergt, J. M., and K. N. Farley (1994), Major element, trace element and isotope $(\mathrm{Pb}, \mathrm{Sr}$, and $\mathrm{Nd})$ variations in Site 834 basalts: Implications for the initiation of backarc opening, Proc. Ocean Drill. Program Sci. Res., $135,471-485$.

Hergt, J. M., and C. J. Hawkesworth (1994), Pb-, Sr-, and Nd-isotope evolution of the Lau Basin: Implications for mantle dynamics during backarc opening, Proc. Ocean Drill. Program Sci. Results, 135, 505-517.

Hey, R. (1977), Tectonic evolution of the Cocos-Nazca spreading center Geol. Soc. Am. Bull., 88, 1404-1420.

Hey, R. N., J. M. Sinton, and F. K. Duennebier (1989), Propagating rifts and spreading centers, in The Geology of North America, vol. N, The Eastern Pacific Ocean and Hawaii, edited by E. L. Winterer, D. M. Hussong, and R. W. Decker, pp. 161-176, Geol. Soc. of Am., Boulder, Colo.

Hirose, K., and T. Kawamoto (1995), Hydrous partial melting of lherzolite at $1 \mathrm{GPa}$ : The effect of $\mathrm{H}_{2} \mathrm{O}$ on the genesis of basaltic magmas, Earth Planet. Sci. Lett., 133, 463-473.

Hirose, K., and I. Kushiro (1993), Partial melting of dry peridotites at high pressures: Determination of compositions of melts segregated from peridotite using aggregates of diamond, Earth Planet. Sci. Lett., 114, $477-$ 489.

Hoernle, K. A., and G. R. Tilton (1991), Sr-Nd-Pb isotope data for Fuerteventura (Canary Islands) basal complex and subaerial volcanics: Applications to magma genesis and evolution, Schweiz. Mineral. Petrogr. Mitt., $71,3-18$.

Hofmann, A. W. (1988), Chemical differentiation of the Earth: The relationship between mantle, continental crust, and oceanic crust, Earth Planet. Sci. Lett., 90, 297-314.

Hofmann, A. W., K. P. Jochum, M. Seufert, and W. M. White (1986), Nb and $\mathrm{Pb}$ in oceanic basalts: New constraints on mantle evolution, Earth Planet. Sci. Lett., 79, 33-45.

Ishikawa, T., and F. Tera (1999), Two isotopically distinct fluid components involved in the Mariana arc: Evidence from $\mathrm{Nb} / \mathrm{B}$ ratios and $\mathrm{B}, \mathrm{Sr}, \mathrm{Nd}$, and $\mathrm{Pb}$ isotope systematics, Geology, 27, 83-86.

Ito, E., W. M. White, and C. Göpel (1987), The O, Sr, Nd and Pb isotope geochemistry of MORB, Chem. Geol., 62, 157-176.
Jenner, G. A., P. A. Cawwood, M. Rautenschlein, and W. M. White (1987), Composition of back-arc basin volcanics, Valu Fa Ridge, Lau Basin: Evidence for a slab-derived component in their mantle source, J. Volcanol. Geotherm. Res., 32, 209-222.

Jenner, G. A., H. P. Longerich, S. E. Jackson, and B. J. Fryer (1990), A powerful tool for high-precision trace element analysis in earth sciences: Evidence from analysis of selected U.S.G.S. reference samples, Chem Geol., 83, 133-148.

Kamber, B. S., and K. D. Collerson (2000), Zr/Nb systematic of ocean island basalts reassessed: The case for binary mixing, J. Petrol., 41, $1007-1021$

Keppler, H. (1996), Constraints from partitioning experiments on the composition of subduction-zone fluids, Nature, 380, 237-240.

Klein, E. M., and C. H. Langmuir (1987), Global correlation of ocean ridge basalt chemistry with axial depth and crustal thickness, J. Geophys. Res. 92, 8089-8115

Loock, G., W. F. McDonough, S. L. Goldstein, and A. W. Hofmann (1990), Isotopic compositions of volcanic glasses from the Lau Basin., Mar. Min., 9, 235-245.

Mahoney, J. J., J. H. Natland, W. M. White, S. H. Poreda, S. H. Bloomer, R. L. Fisher, and A. N. Baxter (1989), Isotopic and geochemical provinces of the western Indian Ocean spreading centers, J. Geophys. Res., 94, 4033-4052

Mahoney, J. J., J. M. Sinton, M. D. Kurz, J. D. Macdougall, K. J. Spencer, and G. W. Lugmair (1994), Isotope and trace element characteristics of a super-fast spreading ridge: East Pacific Rise, $13-23^{\circ} \mathrm{S}$, Earth Planet. Sci. Lett., 121, 173-193.

Martinez, F., and B. Taylor (2002), Mantle wedge control on back-arc crustal accretion, Nature, 416, 417-420.

Martinez, F., and B. Taylor (2003), Controls on back-arc crustal accretion: Insights from the Lau, Manus and Mariana basins, in Intra-oceanic Subduction Systems: Tectonic and Magmatic Processes, edited by R. D. Larter and P. T. Leat, Geol. Soc. Spec. Publ., 219, 19-54.

Miller, D., S. L. Goldstein, and C. H. Langmuir (1994), Cerium/lead and lead isotope ratios in arc magmas and the enrichment of lead in the continents, Nature, 368, 514-520.

Pearce, J. A., and I. J. Parkinson (1993), Trace element models for mantle melting: Application to volcanic arc petrogenesis, in Magmatic Processes and Plate Tectonics, edited by H. M. Prichard et al., Geol. Soc. Spec. Publ., 76, 373-403.

Pearce, J. A., and D. W. Peate (1995), Tectonic implications of the composition of volcanic arc magmas, Annu. Rev. Earth Planet. Sci. Lett., 23, $251-285$.

Pearce, J. A., M. Ernewein, S. H. Bloomer, L. M. Parson, B. J. Murton, and L. E. Johnson (1995), Geochemistry of Lau basin volcanic rocks: Influence of ridge segmentation and arc proximity, in Volcanism Associated With Extension of Consuming Plate Margins, edited by J. L. Smellie, Geol. Soc. Spec. Publ., 81, 53-75.

Peate, D. W., T. F. Kokfelt, C. J. Hawkesworth, P. W. van Calsteren, J. M. Hergt, and J. A. Pearce (2001), U-series isotope data on Lau Basin glasses: The role of subduction-related fluids during melt generation in back-arc basins, J. Petrol., 42, 1449-1470.

Peccerillo, A., and S. R. Taylor (1976), Geochemistry of Eocene calc-alkaline volcanic rocks from the Kastamonu area, northern Turkey, Contrib. Mineral. Petrol., 58, 63-81.

Peirce, C., M. C. Sinha, S. Constable, and EW9512 Scientific Party (1996), R/V Maurice Ewing cruise 9512: Geophysical investigation of melt bodies beneath the Valu Fa Ridge, Lau Basin (SW Pacific), InterRidge News, 5, 3-8.

Perfit, M. R., W. I. Ridley, and I. R. Jonasson (1999), Geologic, petrologic, and geochemical relationships between magmatism and massive sulfide mineralization along the eastern Galapagos spreading center, in Volcanic-Associated Massive Sulfide Deposits: Processes and Examples in Modern and Ancient Settings, edited by C. T. Barrie, and D. Hannington Mark, pp. 75-100, Soc. of Econ. Geol., Littleton, Colo.

Pfänder, J. A., K. P. Jochum, I. Kozakov, A. Kröner, and W. Todt (2002), Coupled evolution of back-arc and island arc-like mafic crust in the lateNeoproterozoic Agardagh Tes-Chem Ophiolite, central Asia: Evidence from trace element and $\mathrm{Sr}-\mathrm{Nd}-\mathrm{Pb}$ isotope data, Contrib. Mineral. Petrol., 143, 154-174.

Plank, T., and C. H. Langmuir (1992), Effects of melting regime on the composition of the oceanic crust, J. Geophys. Res., 97, 19,74919,770 .

Prinzhofer, A., E. Lewin, and C. J. Allegre (1989), Stochastic melting of the marble cake mantle: Evidence from local study of the East Pacific Rise at $12^{\circ} 50^{\prime} \mathrm{N}$, Earth Planet. Sci. Lett., 92, 189-206.

Sims, K. W. W., and D. J. DePaolo (1997), Inferences about mantle magma sources from incompatible element concentration ratios in oceanic basalts, Geochim. Cosmochim. Acta, 61, 765-784. 
Sinton, J. M., D. S. Wilson, D. C. Christie, R. N. Hey, and J. R. Delaney (1983), Petrologic consequences of rift propagation on oceanic spreading ridges, Earth Planet. Sci. Lett., 62, 193-207.

Stackelberg, U. von, and the Shipboard Scientific Party (1988), Active hydrothermalism in the Lau Back-Arc Basin (SW-Pacific): First results from the Sonne 48 cruise (1987), Mar. Min., 7, 431-442.

Stackelberg, U. von (1990, Geoscientific investigations in the Lau Basin, Research Cruise SO 67-2 with RV Sonne 17.3.-28.4.1990, Rep. 107286, 130 pp., Bundesanst. fuer Geowiss. und Rohstoffe (BGR), Hannover, Germany.

Stolper, E., and S. Newman (1994), The role of water in the pertogenesis of Mariana trough magmas, Earth Planet. Sci. Lett., 121, 293-325.

Sun, S.-S., and W. F. McDonough (1989), Chemical and isotopic systematics of oceanic basalts: Implications for mantle composition and processes, in Magmatism in the Ocean Basins, edited by A. D. Saunders and M. Norry, Geol. Soc. Spec. Publ., 42, 313-345.

Sunkel, G. (1990), Origin of petrological and geochemical variations of Lau Basin lavas (SW Pacific), in Hydrothermal Mineralization of the Lau Basin: Results of the Sonne Cruise SO48, edited by J. R. Moore and U. von Stackelberg, pp. 205-234, Taylor and Francis, Philadelphia, Pa Taylor, B., and F. Martinez (2003), Back-arc basin basalt systematics, Earth Planet. Sci. Letts, 210, 481-497.

Taylor, B., K. Zellmer, F. Martinez, and A. M. Goodliffe (1996), Sea-floor spreading in the Lau back-arc basin, Earth Planet. Sci. Lett., 144, 35-40.

Todt, W., R. A. Cliff, A. Hanser, and A. W. Hofmann (1996), Evaluation of a $202 \mathrm{~Pb}-205 \mathrm{~Pb}$ double spike for high precision lead isotope analyses, in Earth Processes: Reading the Isotopic Code, Geophys. Monogr. Ser., vol.95, edited by A. Basu and S. Hart, pp. 429-437, AGU, Washington, D. C.

Turner, I. M., C. Peirce, and M. C. Sinha (1999), Seismic imaging of the axial region of the Valu Fa Ridge, Lau Basin: The accretionary processes of an intermediate back-arc spreading ridge, Geophys. J. Int., 138, 495-519.

Turner, S., and C. Hawkesworth (1997), Constraints on flux rates and mantle dynamics beneath island arcs from Tonga-Kermadec lava geochemistry, Nature, 389, 568-573.
Turner, S., N. R. Hawkesworth, J. Bartlett, T. Worthington, J. Hergt, J. Pearce, and I. Smith (1997), 238U-230Th disequilibria, magma petrogenesis, and flux rates beneath the depleted Tonga-Kermadec island arc, Geochim. Cosmochim. Acta, 61, 4855-4884.

Vallier, F. T. L., et al. (1991), Subalkaline andesite from Valu Fa Ridge, a back-arc spreading center in southern Lau Basin: Petrogenesis, comparative chemistry, and tectonic implications, Chem. Geol, 91, 227-256.

Vlastelic, I., D. Aslanian, L. Dosso, H. Bougault, J. L. Olivet, and L. Geli (1999), Large-scale chemical and thermal division of the Pasific mantle, Nature, 399, 345-350.

Volpe, A. M., J. D. Macdougall, and J. W. Hawkins (1988), Lau Basin basalts (LBB): Trace elements and $\mathrm{Sr}-\mathrm{Nd}$ isotopic evidence for heterogeneity in backarc basin mantle, Earth Planet. Sci. Lett., 90, 174-186.

Wiedicke, M., and J. S. Collier (1993), Morphology of the Valu Fa spreading ridge in the southern Lau Basin, J. Geophys. Res., 98, 11,76911,782

Woodhead, J., S. Eggins, and J. Gamble (1993), High field strength and transition element systematics in island arc and back-arc basin basalts: Evidence for multi-phase melt extraction and a depleted mantle wedge, Earth Planet. Sci. Lett., 114, 491-504.

S. Fretzdorff, C.-D. Garbe-Schönberg, and P. Stoffers, Institut für Geowissenschaften, Abteilung Geochemie, Christian-Albrechts-Universität zu Kiel, Olshausenstrasse 40, D-24118 Kiel, Germany. (sf@gpi.uni-kiel.de)

H. L. Gibson, Department of Earth Sciences, Laurentian University, Sudbury, Ontario, Canada P3E 2C6.

F. Hauff, IFM-Geomar, Dienstgebäude Ostufer, Forschungsbereich 4, Wischhofstr. 1-3, D-24148 Kiel, Germany.

U. Schwarz-Schampera, Bundesanstalt für Geowissenschaften und Rohstoffe (BGR), Alfred-Bentz-Haus Stilleweg 2, D-30655 Hannover, Germany. 